\title{
Does Corporate Social Responsibility Influence Firm Performance of Indian Companies?
}

Supriti Mishra

Damodar Suar

\begin{abstract}
This study examines whether corporate social responsibility (CSR) towards primary stakeholders influences the financial and the non-financial performance (NFP) of Indian firms. Perceptual data on CSR and NFP were collected from 150 senior-level Indian managers including CEOs through questionnaire survey. Hard data on financial performance (FP) of the companies were obtained from secondary sources. A questionnaire for assessing CSR was developed with respect to six stakeholder groups - employees, customers, investors, community, natural environment, and suppliers. A composite measure of CSR was obtained by aggregating the six dimensions. Findings indicate that stock-listed firms show responsible business practices and better FP than the non-stock-listed firms. Controlling confounding effects of stock-listing, ownership, and firm size, a favorable perception of managers towards CSR is found to be associated with increase in FP and NFP of firms. Such findings hold good when CSR is assessed for the six stakeholder groups in aggregate and for each stakeholder group in segregate. Findings suggest that responsible business practices towards primary stakeholders can be profitable and beneficial to Indian firms.
\end{abstract}

KEY WORDS: corporate social responsibility, financial performance, non-financial performance

\section{Introduction}

The relation between corporate social responsibility (CSR) and firm performance has evoked much interest among researchers. While some studies reveal a positive relation between the two constructs (Graves and Waddock, 1994; Griffin and Mahon, 1997; McGuire et al., 1988; Waddock and Graves, 1997), some others indicate a negative relation (Bromiley and Marcus, 1989; Wright and Ferris,
1997), and still others (Aupperle et al., 1985; Teoh et al., 1999) establish no relation between the two constructs. Though a positive relation between CSR and firm performance has prevailed in many studies (Margolis and Walsh, 2003; Orlitzky et al., 2003), results still remain inconclusive (Margolis and Walsh, 2003; Vogel, 2005). Such inconclusiveness creates ground for further investigation.

Corporate social responsibility is predominantly considered as a western phenomenon due to strong institutions, standards, and appeal systems which are weak in developing countries of Asia (Chapple and Moon, 2005). Such weak standards pose considerable challenge to firms for practicing CSR in developing countries of Asia including India. Though extensive research on CSR influencing firm performance has been carried out in developed countries (Belal, 2001), there is a dearth of such studies in India. Current research on CSR in India is mostly limited to selfreported questionnaire surveys on CSR (Khan and Atkinson, 1987; Krishna, 1992), nature and characteristics of CSR in India (Arora and Puranik, 2004; Sood and Arora, 2006), and policies and practices of multi-national corporations (MNCs) towards CSR in India (CREM, 2004) without linking it with firm performance. This study intends to fill that gap. It replicates and extends the past findings (Tsang and Kwan, 1999) on CSR and firm performance of western counties. It is intended to be carried out in a different country, in a different time period, in different industries, and using different measures. Such replications are warranted to establish the external validity of results and to rebuild the confidence of researchers and practitioners on earlier findings.

Operationalization of CSR has often been a source of debate. Researchers have used various 
proxy measures to assess CSR (Aupperle et al., 1985; Cochran and Wood, 1984; Fomburn and Shanley, 1990; McGuire et al., 1988). After introduction of the stakeholder concept (Freeman, 1984), reconfiguration of CSR from stakeholders' perspective has given a new direction to the evaluation of CSR (Clarkson, 1995). Single-dimensional measures of CSR have been replaced by multi-dimensional measures of CSR that include various stakeholder issues. However, studies using the stakeholders' perspective often aggregate the dimensions of CSR towards various stakeholders to one composite index while examining its relation with firm performance (Cochran and Wood, 1984; Ruf et al., 2001; Waddock and Graves, 1997). Such aggregation has facilitated inter-firm comparison on the level of CSR displayed by firms. However, such aggregation has the risk of 'masking individual dimensions' of CSR related to specific stakeholder groups (Galbreath, 2006). With aggregation, a firm's high level of CSR may be driven by favorable CSR policies and practices towards a few stakeholders leaving the issue of other stakeholders fully or partially unattended. Analyzing the influence of such skewed measures of CSR on firm performance may not reflect a true relation between the two constructs. This necessitates examining the influence of individual dimensions of CSR on firm performance. Only few studies have examined the relation between individual CSR dimensions and firm performance (Berman et al., 1999; Graafland and van de Ven, 2006). This study examines the influence of individual as well as aggregate CSR dimensions on firm performance.

Past research has mostly used financial performance (FP) measures to assess firm performance. However, due to the historical nature and rigidity of most of the financial measures, assessment of nonfinancial performance (NFP) along with FP is needed to evaluate firm performance (Govindarajan and Gupta, 1985; Ittner and Larcker, 1998). Because CSR leads to many intangible benefits for the company such as corporate reputation and image (Schwaiger, 2004), increased employee motivation (Epstein and Roy, 2001), improved brand image (Heal, 2005) and the like, NFP that assesses intangible benefits/assets is likely to be influenced by CSR. While the influence of CSR on FP is a widely researched area (Zahra and LaTour, 1987), its influence on NFP is a sparsely investigated topic. This study examines the influence of CSR on both FP and NFP of Indian companies.

\section{Conceptual background and hypotheses development}

\section{CSR in India}

Asian firms often lag behind their Western counterparts on CSR practices (KPMG, 2005). However, advent of liberalization and globalization, entry of MNCs in Asian markets, rising consumer expectations towards business, and emergence of pressure groups have made the case of CSR stronger in Asian countries including India. But Indian companies mostly focus their CSR activities on community development (PiC, 2004). Philanthropic orientation of Indian businessmen has its roots in history. In the early nineteenth century India, CSR was mainly found in the form of philanthropic contributions by Gujrati and Parsi merchant communities, who provided funds for building schools, pilgrim rest houses, places of worship like temples, distributing relief items during disasters, and helping the poor.

A 20-country public opinion survey finds that India is the last in the level of CSR demanded from companies in any country (Environics International, 2001). A lack of provable link between CSR and firm performance often discourages companies from engaging in CSR (British Council et al., 2002). Obstacles to CSR are found to be ad hoc approach by the top management towards CSR, lack of consensus on priorities within the firm, and problems related to measurement and evaluation of CSR activities (Krishna, 1992). Unclear policies, bureaucracy, poor monitoring, complicated tax systems, and poor infrastructure are a few more hindering factors (CSM, 2001). However, there is a growing feeling among the Indians that business organizations must play a wider role in the society besides providing quality products at reasonable rates, making their operations environmentally sound, adhering to high labor standards, and reducing human rights abuses at the work place (Kumar et al., 2001). Consequently, Indian companies have started changing their outlook towards CSR by looking beyond passive philanthropy. Companies are 
considering CSR for improved brand image and stronger ties with the local community (British Council et al., 2002; PiC, 2004).

\section{CSR from stakeholders' perspective}

The approach of business organizations to CSR has transcended from merely displaying social concerns to being sensitive and alert to the constituents in the internal and external business environment. These constituents, known as stakeholders, are potent forces to accelerate or decelerate a firm's performance. With globalization of national boundaries and information technology revolution, companies are under tight scrutiny from multiple stakeholders including regulators, investors, customers, pressure groups, and the public at large. Corporate scandals are making big news leading to crumbling of wellsettled business empires. Recent sub-prime crisis in the US and the subsequent crashing of stock indices of companies across the globe is a case in point. When stakeholders loose confidence in a firm's performance, the firm loses its critical support structure and customer base (Lee, 2008). Customers stop buying products or go for legal suits, shareholders sell their stocks, employees do not perform, and environmental advocates sue (Wood, 1991), all of which directly affect firm performance. This warrants pursuing meaningful and long-term relations with stakeholders.

A firm's survival and success depends on the ability of its managers to create sufficient wealth and satisfaction for its primary stakeholders (Clarkson, 1995). Primary stakeholders of a firm include employees, shareholders, customers, suppliers, communities, and natural environment. If any of the primary stakeholder groups withdraws its support to the firm, the firm's operation is adversely affected (Clarkson, 1995). Firms that establish relationship with primary stakeholders beyond market transactions gain competitive advantage (Barney and Hansen, 1994; Fomburn and Shanley, 1990). Effective management of key stakeholders acts as a value driver by leveraging performance and reducing stakeholder-inflicted costs. Lower employee turnover reduces hiring and training costs, loyal suppliers reduce quality certification costs, supportive communities reduce legal and public relations overhead, and stable shareholders reduce stock market volatility (McVea and Freeman, 2005). In order to achieve sustainability in business, firms must identify key stakeholders affecting the firm, identify their needs, and design organizational policies and practices to cater to them. Accordingly, we define CSR towards a particular stakeholder group as a firm's policies, processes, and practices towards that stakeholder group. The study recognizes primary stakeholders as key stakeholders and defines CSR from their perspective.

\section{Measurement of CSR}

Past studies on CSR have often been criticized for using inappropriate measures of CSR. Researchers have used various proxy measures to assess CSR: (a) one-dimensional surrogate measures such as reputation ranking of companies on pollution control performance (Chen and Metcalf, 1980; Freedman and Jaggi, 1982), (b) Moskowitz's social responsibility ratings (Cochran and Wood, 1984; Moskowitz, 1972), and (c) Fortune corporate reputation index (Fomburn and Shanley, 1990; McGuire et al., 1988). These measures have been criticized for their inability to incorporate stakeholders' issues (Aupperle et al., 1985; Ullman, 1985). To overcome such inadequacies, recent studies (Ruf et al., 2001; Waddock and Graves, 1997) use CSR data developed by various agencies that evaluate CSR from stakeholders' perspective such as the KLD database of Kinder, Lydenberg, Domini \& Co., Inc. (Kinder et al., 2005).

Voluntary standards such as ISO 14000, OHSAS 18000, Social Accountability (SA) 8000 (SAI, 2001), United Nations' global compact, and Global Reporting Initiative guidelines (GRI, 2002) outline a wide range of responsible business practices related to stakeholder issues such as environment, occupational health and safety, labor, human rights, corruption, etc. In recent years, an increasing number of companies are making CSR disclosures as per these standards. Nearly $90 \%$ of Fortune 500 firms make CSR disclosures in their annual reports (Boli and Hartsuiker, 2001). However, Indian companies lag behind their global counterparts in terms of CSR disclosure. A recent survey of 27 companies by KPMG finds that only $25 \%$ of the companies are signatories to GRI guidelines, $8 \%$ mention about 
their social expenditures, and 25\% file CSR reports (Handique, 2008). There is no systematic CSR database of companies in India. There are two widely used secondary database on Indian companies, Prowess database of Centre for Monitoring Indian Economies (CMIE) (Prowess, 2005) and India Business Insight Database (IBID) of Informatics India Limited (2003). The former gives access to corporate governance reports and the latter includes newspaper articles on corporate activities including CSR initiatives. Number of mandatory standards included in the Indian Companies Act, 1956, the Securities and Exchange Board of India (SEBI) guidelines, various pollution prevention acts, and the like give dispersed ideas about the responsibilities of Indian companies to different stakeholders. In this context, this study develops a comprehensive measure of CSR towards each primary stakeholder group incorporating corresponding social, ethical, legal, and economic issues derived from local and global standards.

\section{Firm performance}

Griffin and Mahon (1997) have reviewed 51 studies on CSR-firm performance relationship and found that as many as 80 different types of FP measures have been used. Firm size, return on assets (ROA), return on equity, asset age, and return on sales are the frequently used FP measures. Particularly, ROA is consistently claimed to be an authentic measure of FP (Berman et al., 1999; McGuire et al., 1988). Unlike other accounting measures such as return on equity or return on sales, ROA is not affected by the differential degree of leverage present in firms. Because ROA is positively correlated with the stock price, a higher ROA implies higher value creation for shareholders. Moreover, in asset-heavy firms such as the manufacturing firms, ROA is a better indicator of firm performance.

Financial performance measures are lag indicators and capture historical performance arising from mostly tangible assets (Ong, 2003). They often fail to properly record performance from intangible assets such as customer relationships, employee satisfaction, innovation, investment in research and development, and the like that have become significant sources of competitive advantage for firms in recent times (Lev, 2000). In contrast, NFP measures focus on a firm's long-term success factors such as research and development, customer satisfaction, internal business process efficiency, innovation, and employee satisfaction, and capture performance improvements from intangible assets (Kaplan and Norton, 2001). Investments in intangible assets such as research and development are expensed immediately instead of getting capitalized in the traditional accounting system. Such treatment of intangible assets depresses the profit in the current year though benefits from such investments accrue to the firm over a long period of time. By accounting for such performance improvements, NFP measures provide indirect indicators of firm performance. Because of their focus on consequences rather than causes of performance, NFP measures are considered as 'lead indicators' (Ittner and Larcker, 2000). FP measures are objective in nature whereas NFP measures are subjective in nature that includes managers' perception of firm performance on market share, employee health and safety, investment in research and development, and others. Perceptual data on NFP from senior managers correlate with hard data on FP from secondary sources (Venkatraman and Ramanujam, 1987) suggesting their complementarity. Hence, FP measures along with NFP measures are used to assess firm performance holistically (Govindarajan and Gupta, 1985; Ittner and Larcker, 1998).

\section{CSR and firm performance}

The relations between CSR and FP are mostly inconclusive, but positive relations between the two have been reported in most of the studies (Margolis and Walsh, 2003) suggesting an instrumental orientation of CSR initiatives. An instrumental orientation towards CSR suggests the alignment of the social goal with the business goal where CSR is considered as a strategic tool to promote the economic objective of the firm. Managers foresee significant value additions in firm performance due to strengthened stakeholder relations. Management theorists argue that by improving CSR towards stakeholders, firm performance is augmented (Waddock and Graves, 1997). 
The influence of stakeholder-oriented CSR on firm performance can be understood with the help of three theories: (a) consumer inference making, (b) signaling theory, and (c) social identity theory. 'Consumer inference making' theory suggests that if a consumer knows that the manufacturer of the product is a responsible firm, s/he can infer positively about the product (Brown and Dacin, 1997). Such inferences induce consumer goodwill (Brown and Dacin, 1997; Handelman and Arnold, 1999) that influences purchase intention (Gildea, 1994; Owen and Scherer, 1993). 'Signaling' theory (Boulding and Kirmani, 1993; Kirmani, 1997) suggests that in situations where there is information asymmetry between buyers and sellers, consumers look for information/signals that distinguish companies performing well on attributes of interest compared to companies performing poorly. Signals such as warranties (Boulding and Kirmani, 1993) indicating reliability and higher quality of products enable consumers to decide between companies. Consumers associate higher product quality with proactive corporate citizenship (Maignan and Ferrell, 2001) and potential job-seekers value CSR record of companies as a signal for organizational attractiveness (Greening and Turban, 2000; Turban and Greening, 1997). 'Social identity' theory emphasizes that one's self-concept is influenced by membership in different social organizations, including the company for which an individual works (Ashforth and Mael, 1989; Dutton et al., 1994). Employees' self-image is influenced by the image and reputation of their employers, consumers identify themselves with organizations or brands involved in discretionary citizenship (Aaker, 1994; Belk, 1988), and institutional investors like to be associated with socially responsible firms (Graves and Waddock, 1994; Teoh and Shiu, 1990). Such bonds of identification encourage positive evaluations of a firm's products, and reap value addition through customer loyalty, advocacy, positive words-of-mouth, and resilience to negative brand information (Hoeffler and Keller, 2002; Sen et al., 2006).

Alternatively, irresponsible behavior by firms agitates stakeholders. They often react by boycotting the company (Hayes and Pereira, 1990), reducing consumption of the company's products (Sen and Bhattacharya, 2001), initiating legal action against the company (Greeno and Robinson, 1992), and/or spreading bad words-of-mouth about irresponsible business practices (Clair et al., 1995). Boycotting of Nike products due to human rights' abuse and unsafe working conditions at suppliers' locations in Asia (Herbert, 1996), or sharp reaction from environmentalists and consumers to the pesticide content in Pepsi and Coca-Cola beverages in India (Financial Express, 2006) are few such instances. While improved stakeholder relations have the potential to improve a firm's reputation and performance, strained relations have the risk of adversely affecting a firm's performance. Hence, we propose:

$H_{1}$ : The favorable CSR towards stakeholders will positively impact the firms' FP and NFP.

Because we have considered CSR towards six groups of stakeholders, let us examine the relationship between CSR towards each stakeholder group and firm performance.

\section{CSR towards employees and firm performance}

Proactive policies and practices towards employees reflect a company's intention to address the interests of its employees and satisfy their needs. Policies and practices towards union relations, employees' participation in decision making, remuneration policy, working conditions, and elimination of forced/child labor, portray a firm's CSR towards employees. By adhering to such standards, firms can satisfy employees, enhance their job performance, and improve FP and NFP. The Energy Research Institute's report mentions that Indian stakeholders including workers, company executives, and general public feel that Indian companies should adhere to higher labor standards and reduce human rights abuses at the workplace (Kumar et al., 2001). Working conditions that respect human dignity, equality, and social protection result in a productive workplace (Somavia, 2000). Social responsibility of a company is a reputation factor and is an attractive force for potential and current employees (Turban and Greening, 1997). Ethical reputation contributes to job satisfaction and lower employee turnover by evoking positive reactions from employees' families and friends (Riordan et al., 1997). Because satisfied employees have higher morale and job motivation, they will work more effectively and efficiently (Berman et al., 1999) and contribute to higher levels 
of organizational effectiveness (Koys, 2001). Past studies establish that better human resource management practices such as training and development of employees, their participation in problem solving, progressive remuneration policies, and grievance procedures reduce employee turnover, increases their productivity and FP (Huselid, 1995; Youndt et al., 1996). A better CSR towards employees which includes wider issues compared to human resource management issues also improves a firm's FP (Berman et al., 1999). Hence,

$H_{1.1}$ : The favorable CSR towards employees will positively impact the firms' FP and NFP.

CSR towards customers and firm performance

Positive customer perception about product quality and safety leads to increased sales or decreased costs associated with stakeholder relationships (Waddock and Graves, 1997). Higher product safety and quality improves the bottom line (Berman et al., 1999). In product retailing, market reactions are found to be negative for socially irresponsible companies (Bromiley and Marcus, 1989; Davidson and Worell, 1988). When customers are dissatisfied with a product or its associated services, investors apprehend that negative customer reactions in the form of decreased patronage, lawsuits, or both, will directly affect the bottom line (Berman et al., 1999). Event studies establish that market value of a company decreases when corporate irresponsibility and illegal behavior is observed (Frooman, 1997). The news of pesticide content in Pepsi and Coca-Cola beverages in India reduced the sales of both companies by $60 \%$ (Financial Express, 2006). Continuous deterioration in quality directly affects firm performance (Landon and Smith, 1997). Hence, companies need to be careful about factors such as ethical advertising standards, customer health and safety during product use, company-wide quality programs for providing better products at right prices and the like. Company policies and practices to address such issues give a positive signal about a company's responsible attitude towards its customers and can improve firm performance. Hence,

$H_{1.2}$ : The favorable CSR towards customers will positively impact the firms' FP and NFP.
CSR towards investors and firm performance

Firms can strengthen their investor relations by adopting proper governance standards. After the corporate governance debacles in 1990s such as that of Enron in the US, the stock market crisis in India, and falling corporate governance standards across the globe, a lot of importance is being given to governance codes and laws for protecting the interests of shareholders and investors. These codes stress the need for transparency in financial and non-financial disclosures, adoption of internationally compatible accounting standards, appropriate board processes and information systems, and compliance with legal and regulatory requirements. CSR towards investors examine firm policies and practices towards such issues including shareholders' participation in decision making, auditors' independence, and policies towards insider trading. Evidence suggests that adoption of better corporate governance standards increases firm performance. Investors show willingness to pay a premium for the stocks of well-governed companies compared to poor-governed companies (Coombes and Watson, 2000). Companies with the highest rankings in good governance practices also have the highest FP (Business Week, 2002). Positive relations are found between corporate governance and stock price performance and financial ratios in emerging markets (CLSA, 2000). Companies ranked in the top quarter of corporate governance yield a better average return on capital employed compared to companies ranked in the bottom half (CLSA, 2000). Companies that comply with the Cadbury Committee recommendations in the UK experience better performance as compared to the noncomplying firms (Dahya and McConnell, 2007). Past research on the influence of corporate governance indicators such as board size on firm performance has yielded both positive (Dalton et al., 1998) and negative outcomes (Alshimmiri, 2004). However, in the Indian context, studies suggest that properly designed mandatory corporate governance reforms increase share prices (Black and Khanna, 2007). Market value of Indian companies such as Infosys that follows stricter governance and disclosure standards increased as high as 2000 times while that of poor governed firms declined as low as 95\% during 1995-2000 (Nemkumar, 2000). Hence, 
$H_{1.3}$ : The favorable CSR towards investors will positively impact the firms' FP and NFP.

CSR towards community and firm performance

Typical involvement of business with the community is seen in areas of education, health, and income generation. CSR towards community is seen in terms of philanthropic giving, public-private partnerships, community relationships, and participation in social and economic development issues. Of late, companies are pursuing meaningful partnerships with non-governmental organizations (NGOs) to empower the local community. Endeavors by Indian companies such as Kishan Kendras ${ }^{1}$ by Tata group, e-Choupals and KisanIndia.com by ITC, Shubh Labh ${ }^{2}$ services by Mahindra, and Kisan Kendra by Ralli empower rural Indian farmers (Singh and Bhagat, 2004). Initiatives by MNCs such as Microsoft's partnership with an NGO, Pratham, to promote quality primary education in rural India (Brugmann and Prahalad, 2007) or Hewlett Packard's living lab experiment with women self-help groups in rural Andhra Pradesh (India) to provide them sustainable livelihoods (Dunn and Yamashita, 2003) are few more examples. When firms focus their social actions on communities in and around their area of operation, they reap the benefits of a socially responsible image among their employees and the local community (Husted, 2003). Partnership of Life Insurance Corporation of India with micro-credit federations in the rural Andhra Pradesh, besides improving its penetration of the rural market and expanding the customer base, has also increased its gross margin by 27\% (Brugmann and Prahalad, 2007). Indian Market Research Bureau finds that after Hindustan Lever Limited, a fast moving consumer goods company, launched an initiative called 'Project Shakti' for creating livelihood of rural women in India, the consumption of its products increased in the range 15-20\% (Sood and Arora, 2006). Though past evidence suggests a negative relation between CSR towards the community and firm performance (Berman et al., 1999), it is also observed that investments in community development activities help a firm to obtain competitive advantages through tax savings, decreased regulatory burden, and improvements in the quality of local labor (Waddock and Graves, 1997). Hence,
$H_{1.4}$ : The favorable CSR towards community will positively impact the firms' FP and NFP.

CSR towards environment and firm performance

Recent years have seen mounting global pressure for enactment and adoption of stricter legislations pertaining to environment protection in and around the globe. Companies are taking proactive initiatives for emission reduction in anticipation of future policy, and societal and competitive developments with respect to environment. With increasing importance of environmental friendly products, processes, and services, firms are realizing the importance of adopting environmental standards for their sustainability in the long run. This has facilitated development of green resources and capabilities and compliance with international standards such as ISO 14000, OHSAS 18000 , and environmental legislations. Environmental performance is enhanced by improvements in three aspects - (a) product technologies such as use of recycled raw materials and other resource saving programs, (b) process technologies such as use of efficient production systems and end-of-pipe controls, and (c) management systems such as workers' training programs and environmental audit. Global standards on CSR towards environment endorse these aspects. Research on environmental proactivity has not been conclusive (Christman, 2000). But studies link environmental commitment with enhanced profitability, particularly in high growth industries (Russo and Fouts, 1997). Evidence suggests proactive environment management enhances firm's market value (Klassen and Mc Laughlin, 1996), reputation, and FP (Alvarez et al., 2001; Miles and Covin, 2000). The impact of firms' proactive environmental practices on market share, profitability, and return on investment is better in environmentally conscious companies compared to not-soconscious companies (Ahmed et al., 1998). Hence,

$H_{1.5}$ : The favorable CSR towards environment will positively impact the firms' FP and NFP.

CSR towards suppliers and firm performance

Influence of suppliers has become crucial in recent years as companies have started focusing more on their core competencies, outsourcing other 
functions to suppliers (Prahalad and Hamel, 1990). Recent years have seen growing importance of suppliers' issues such as health and safety, environmental impact, community involvement, and the payment of living wages to employees at both outsourced plant locations and home locations of suppliers. Standards on CSR towards suppliers incorporate such issues besides including issues such as ethical procurement of raw materials by suppliers, and elimination of child labor and human rights' violation at suppliers' locations. By ensuring adherence of CSR standards by suppliers, a firm sends strong signals about its commitment towards CSR, which improves its image and performance. Violation of CSR standards by suppliers adversely affects a firm's performance. Banning of Indian carpet-making firms by international buyers for their use of child labor in carpet making is a case in point. International buyers prefer Rugmark certification which ensures that a firm has not used child labor. Such preferences improve firm performance. Hence,

$H_{1.6}$ : The favorable CSR towards suppliers will positively impact the firms' FP and NFP (Figure 1).

\section{Control variable}

First, firms that are listed in stock exchanges tend to disclose more CSR related information compared to the non-listed firms as performance of listed firms is continuously monitored and evaluated by multiple stakeholders such as investors, financial analysts,

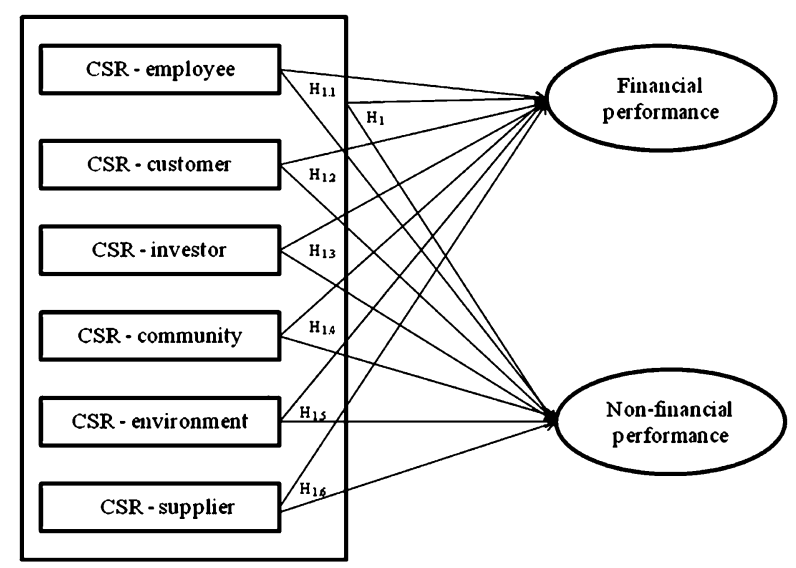

Figure 1. Conceptual model depicting the influence of CSR on FP and NFP. media, and the like. Positive CSR disclosures have positive influence on stock prices (Anderson and Frankle, 1980; Shane and Spicer, 1983). Better CSR of a firm influences investment decisions of institutional investors by improving a firm's access to capital (Graves and Waddock, 1994; Pava and Krausz, 1996) and reducing the cost of capital. Thus stock-listing of companies influences both CSR and firm performance. Second, type of ownership of companies, state-owned or private-owned, affects both the CSR and firm performance. State-owned enterprises (SOEs), which laid the foundation of industrialization in India, coexist with private sector companies in many key sectors. SOEs are generally identified with characteristics such as larger work force, stronger labor laws, employee-friendly work environment and benefit plans, and higher investment on peripheral development. Private sector companies lag with respect to such characteristics. Profit motive is not the primary focus of SOEs like private enterprises. This suggests the prevalence of more CSR in SOEs compared to private enterprises. In a review of 54 studies in different countries on SOE versus private sector performance, 32 show private companies to be more profitable than SOEs (Boardman and Vining, 1989). Similar findings are concurred in the Indian manufacturing sector (Ganesh, 2001). This suggests that type of ownership affects both CSR and firm performance. Third, firm size also influences CSR (Fomburn and Shanley, 1990) and firm performance (Robins and Wiersema, 1995). Larger firms are relatively better positioned than smaller firms to invest more funds for CSR activities. Past research has considered annual sales (Fomburn and Shanley, 1990), total assets, and number of employees (Waddock and Graves, 1997) as indicators of firm size. Because listing in stock exchanges, type of ownership, and firm size are likely to influence CSR and firm performance, without controlling their confounding effects, the CSR-firm performance link cannot be gauged appropriately.

\section{Method}

Sample

Data were collected from Indian manufacturing companies included in the Prowess database of 
CMIE, the largest database of Indian companies. Three criteria were set for inclusion of companies in the sample: (a) minimum capital investment of 250 million (Indian rupees), (b) a minimum number of 100 employees in the firm, and (c) a minimum of 5 years of manufacturing operation. Such criteria excluded small firms and start-up units from the sample. As per the Prowess database (Prowess, 2005), there are 2932 manufacturing companies in India with a minimum capital investment of 250 million (Indian rupees). Out of these, 85 companies are SOEs and the rest are private sector enterprises. Fifteen hundred companies (51\% of the total number of companies in Prowess) were randomly selected from the database representing 18 categories of manufacturing industries. Out of the selected companies, 150 companies responded to the questionnaire survey and the response rate was $10 \%$. Out of the 150 respondent companies, 31 were SOEs and 119 were private sector enterprises, and 101 were listed in Indian stock exchanges (Bombay Stock Exchange and National Stock Exchange), and 49 were not listed in any stock exchange. As CSR decisions are mainly taken by the top management in firms, CEOs and in their absence senior executives such as vice-presidents, directors, senior general managers, or general managers participated in the survey. Data were collected from industrial belts of eight major cities situated in six states out of 35 states and union territories representing India.

A web-enabled version of the questionnaire was developed and sent through e-mail to 900 companies which had e-mail ids. After three reminders over a period of 2 months, only 23 (2.5\%) CEOs returned the filled-in questionnaires through e-mail. Questionnaires were sent to another 600 companies by post which did not have any e-mail id. Though return envelopes along with postage were attached with the questionnaire, only 10 companies returned the filled-in questionnaires within a period of 4 months. Finally, out of the non-responding companies, 400 companies were directly contacted by the researcher at their corporate head offices in the north, south, and east zones of India. Prior communication was made to companies through e-mail or telephone, and appointments were fixed with the top executives. In the first meeting with the senior executives, the researcher left the questionnaire with them after explaining the objective of the survey. Because the questionnaire covered a wide range of issues concerning different departments such as the human resource department (employees), marketing department (customers), purchase department (suppliers), and the like, the executives took time to fill up the data in consultation with the concerned departments. After a period of 2 weeks, respondents were contacted to return the filled-in questionnaires. From the 400 companies, filled-in questionnaires were procured from 117 companies. All in all, $150(23+10+$ 117) questionnaires were obtained.

Demographic details of executives were collected as part of the questionnaire survey. Data on age, years of service, education, and monthly salary of CEOs and top-level executives ( $M$ age $=49.53$, $\mathrm{SD}=7.13 ; \quad M$ years of service $=13.79, \quad \mathrm{SD}=$ 10.19; $M$ years of formal study $=18.74, \mathrm{SD}=2.22$ ) were obtained through questionnaire surveys. Among the respondents, 92\% had at least one professional qualification like engineering or management degree. Average monthly gross salary of respondents in various industries varied from as low as 35,000 (Indian rupees) to as high as 1,257,261 (Indian rupees). Respondents were male members in 146 of the 150 firms indicating the low representation of women in the top management. The sample companies had a minimum number of 105 employees and a maximum number of 446,721 employees. The public sector companies had average employee strength of 22,026 within a range 265-446,721. The average employee strength in private sector companies was 2227 within a range 105-40,000. The average employee strength in the 18 categories of industries was within a range 2707953. The sample profile of the 18 categories of industries is summarized in Table I.

\section{Measures}

Besides socio-demographic variables of the respondents, data on CSR towards different stakeholders along with NFP were procured through questionnaire. Respondents were assured complete anonymity of their responses.

\section{CSR}

Items for assessing CSR towards six stakeholder groups were developed after examining the issues 


\section{TABLE I}

Sample profile of surveyed industries

\begin{tabular}{|c|c|c|c|c|c|}
\hline \multirow[t]{2}{*}{ Type of industry } & \multirow{2}{*}{$\begin{array}{c}\text { No. of } \\
\text { companies }\end{array}$} & \multicolumn{2}{|c|}{ Ownership } & \multirow{2}{*}{$\begin{array}{c}\text { Average } \\
\text { employee } \\
\text { (Min-Max) }\end{array}$} & \multirow{2}{*}{$\begin{array}{l}\text { Average monthly } \\
\text { gross salary } \\
\text { (in Indian rupees) } \\
\text { (Min-Max) }\end{array}$} \\
\hline & & Public & Private & & \\
\hline Automobile & 11 & 1 & 10 & $2600(350-12,089)$ & $291,515(31,300-1,228,831)$ \\
\hline Cement & 5 & - & 5 & $1471(478-5027)$ & $162,100(25,500-600,000)$ \\
\hline Chemicals and fertilizers & 14 & 1 & 13 & $696(105-1800)$ & $139,036(35,000-500,000)$ \\
\hline Coal and lignite & 1 & 1 & - & $446,721(-)$ & $42,000(-)$ \\
\hline Construction & 3 & 3 & - & $1633(849-2550)$ & $40,454(38,000-44,361)$ \\
\hline Consumer goods and food products & 13 & 1 & 12 & $7889(300-36,000)$ & $865,267(29,000-9,323,000)$ \\
\hline Crude oil and natural gas & 8 & 5 & 3 & $7953(200-34,722)$ & $65,609(32,000-125,000)$ \\
\hline Drugs and pharmaceuticals & 12 & - & 12 & $1571(410-5700)$ & $1,257,261(42,000-8,275,000)$ \\
\hline Electricity & 10 & 5 & 5 & $2965(131-24,044)$ & $59,935(22,000-120,000)$ \\
\hline Electronics and telecom & 4 & - & 4 & $270(157-500)$ & $92,859(41,435-195,000)$ \\
\hline Machinery & 24 & 9 & 15 & $4900(142-43,000)$ & $90,596(35,000-570,000)$ \\
\hline Other agricultural products & 3 & - & 3 & $981(473-1800)$ & $86,000(54,000-130,000)$ \\
\hline Paper and paper products & 2 & - & 2 & $589(548-630)$ & $43,000(41,000-45,000)$ \\
\hline Plastics and polymers & 5 & - & 5 & $554(200-1200)$ & $53,500(34,000-76,000)$ \\
\hline Shipping & 1 & 1 & - & $3508(-)$ & $35,000(-)$ \\
\hline Steel and aluminum & 18 & 3 & 15 & $4682(150-40,000)$ & $133,189(32,000-841,954)$ \\
\hline Textiles & 13 & - & 13 & $1795(290-43,600)$ & $196,548(30,000-1,483,000)$ \\
\hline Tyres and tubes & 3 & 1 & 2 & $901(280-1462)$ & $1,448,056(28,500-4,235,667)$ \\
\hline Total & 150 & 31 & 119 & $6319(105-446,721)$ & $307,172(22,000-9,323,000)$ \\
\hline
\end{tabular}

covered under various global standards such as KLD database (Kinder et al., 2005), GRI guidelines (GRI, 2002), SA 8000 (SAI, 2001), and relevant ISO standards. We also referred to local standards specified in the Indian Companies Act, 1956, the SEBI guidelines, and pollution prevention acts in India with respect to air, water, and noise, and voluntary codes such as the UNDP-CII social code for business, jointly developed by the Confederation of Indian Industries (CII) and United Nations Development Program (UNDP). In addition, the 27-item scale developed by Benito and Benito (2005) was adopted for the environmental section of the questionnaire.

An initial pool of 70 items was reduced to 61 after pilot testing of the questionnaire in 10 companies. The 61 items were given to three experts working in the area of CSR. They were asked to judge the appropriateness of the items to assess CSR of Indian manufacturing companies towards the six stakeholders. All these items were agreed to by the three experts and were retained for the final survey. In addition, the convergent validity of the constructs was tested by confirmatory factor analysis (CFA). Along with descriptive statistics, unstandardized and standardized regression weights, various fit measures of goodness of fit index (GFI), comparative fit index (CFI), normed fit index (NFI), and root mean square error of approximation (RMSEA) of the scales were obtained (see Table $\mathrm{V}$ in Appendix). Minimum of the model was achieved indicating the fit of each CSR construct to data. Because items were causal indicators and not affect indicators (Bollen and Lenox, 1991), few items had non-significant loadings. Despite the non-significant loadings, we retained them because they represented distinct issues relevant to the stakeholder groups and each construct had high inter-item consistency (Cronbach alpha $\geq 0.70$ ).

Corporate social responsibility was measured separately for each stakeholder (see Table V in Appendix for item details). Thirteen items assessed CSR towards employees including issues such as equal opportunity action plan, anti-discrimination policies, and provisions covering health and safety at work (Cronbach 
alpha $=0.74)$. Seven items examined CSR towards customers covering issues such as commitment to provide quality products and services, pricing products as per quality, and voluntary codes for advertising $($ Cronbach alpha $=0.70)$. Seven items evaluated CSR towards investors including issues such as investor grievance handling policies, rules to strengthen auditor's independence, and policies towards prohibiting insider trading (Cronbach alpha $=0.72)$. CSR towards community was evaluated with 12 items comprising issues such as supporting third party social and sustainable development initiatives, and community partnerships $($ Cronbach alpha $=0.78)$. Issues such as systems for measuring environmental performance, end-of-pipe controls, and environmental training for managers were included in the 17 items assessing CSR towards natural environment (Cronbach alpha $=0.91)$. CSR towards suppliers was evaluated on five items (Cronbach alpha $=0.76)$ including issues such as safety and environmental aspects, and policies on the restrictions of sweat shop/human rights' violation at suppliers' locations. Each respondent was asked to endorse the degree of compliance of the firm with respect to the issues mentioned in the questionnaire. Response descriptions against each item were given on a five-point scale - 'it is not in the company code' $(=1)$, 'it is in the company code but not implemented' $(=2)$, 'it is in the company code but partially implemented' $(=3)$, 'it is in the company code and substantially implemented' (=4), and 'it is in the company code and fully implemented' (=5). The summative score on all items of CSR towards a particular stakeholder group was divided by the number of items to keep that value within the range of the scale.

Aggregation of CSR in the past research has been done by (a) adding various dimensions (Moore, 2001), and (b) assigning weights to the various dimensions on the basis of expert panel ratings (Waddock and Graves, 1997). In order to assess whether all the dimensions of CSR could be added to one aggregate variable, CFA was carried out on the scores of six dimensions of CSR. The relative chi-square value $\left(\chi^{2} / \mathrm{df}=3.54\right)$ of the one-factor model was not below the recommended cut-off criterion of 3. However, the other fit measures GFI $(=0.92)$, CFI $(=0.96)$, and NFI $(=0.94)-$ were above the recommended cut-off criterion of 0.90 (Bollen, 1989) suggesting the fit of the model.
Moreover, the response descriptions against each item of CSR measures were on a uniform five-point scale. Therefore, the scores on six segregated measures of CSR were averaged to specify the aggregate CSR. The inter-item alpha reliability of all the 61 items was high (Cronbach alpha $=0.88$ ).

\section{Firm performance}

$F P$. In order to control industry influences, FP was assessed using industry-adjusted ROA. Industryadjusted ROA was obtained by subtracting average industry ROA of each industry category from the ROA of each firm in the corresponding industry category (Agle et al., 1999; Fowler and Schmidt, 1988). Data on ROA for each of 150 firms and each of 18 categories of industries were collected from the CMIE-Prowess database for 3 years from 20032004 to 2005-2006. ROA of companies, whose data were not available in the database, was calculated from the balance sheets of companies available in annual reports for the above 3 years as the ratio of operating income to total assets $[\mathrm{ROA}=\{\mathrm{Net}$ operating income $\times(1-$ tax rate $)\} /$ Average operating assets] (Copeland et al., 2000). A 3-year average of firm-level and industry-level ROAs was obtained to eliminate possible biases that may result from a single-year figure.

NFP. A 12-item scale developed by Govindarajan (1984) and modified by Hoque (2004) was considered to assess the NFP. The 12 items in the modified version are: (1) sales growth rate, (2) market share, (3) operating profits, (4) workplace relations, (5) cash flow from operations, (6) return on investment, (7) new product development, (8) market development, (9) research and development, (10) cost reduction programs, (11) personnel development, and (12) employee health and safety. Senior managers were requested to indicate the relative position of their companies with respect to the industry average on each item. Response descriptions against each item were given on a five-point scale - 'well below average' $(=1)$, 'below average' (=2), 'average' (=3), 'above average' (=4), 'well above average' $(=5)$. NFP on all items were obtained for 3 years from 2003-2004 to 2005-2006. The annual average value of NFP $\left[\left(\mathrm{NFP}_{2003-2004}+\mathrm{NFP}_{2004-2005}+\mathrm{NFP}_{2005-2006}\right) / 3\right]$ for each of the 12 items was calculated. On such average, items had high inter-item consistency 
$($ Cronbach alpha $=0.89)$. The annual average value of NFP on 12 items was further averaged by dividing it with the number of items to keep the value within the range of the scale. High average score indexed high NFP.

\section{Control variable}

Listing in stock exchanges, type of ownership, and firm size were the control variables. Data on stocklisting status, ownership type, and annual sales were obtained from the CMIE-Prowess database. Data on number of employees were obtained from the respondents. Stock-listing status and ownership type were coded as dummy variables (non-listed $=0$, listed $=1$; public $=0$, private $=1)$. Two indicators of firm size were considered for the study, (a) number of employees (as on 31 March, 2006) and (b) average sales (average of 3 years' net sales from 2003-2004 to 2005-2006), which were continuous variables. From the data of annual sales for 3 years, the average annual sales figure was considered for analysis.

\section{Results}

Descriptive statistics and Pearson correlation among the studied variables are presented (Table II). Positive correlations were found between stock-listing status and aggregate CSR indicating that listed companies showed a higher CSR. Positive correlations between stock-listing status and FP implied that listed companies performed better than nonlisted companies. However, stock-listing status did not relate to NFP. Similarly, the other two control variables, type of ownership, and the firm size did not relate to FP and NFP. Correlation results showed that FP and NFP of the companies were related indicating a higher FP also implied a higher NFP. The correlation between CSR and firm performance indicated that a more favorable aggregate CSR towards all the six stakeholders - employees, customers, investors, community, environment, and suppliers - resulted in a higher industry-adjusted ROA and NFP of the firms. A favorable CSR towards each of the six stakeholders also enhanced the FP and NFP of firms.
The correlation between two variables incorporates bidirectional relations that are unreserved in regression analysis. To examine the influence of control variables, aggregate CSR, and segregate CSR on FP and NFP of firms, hierarchical regression analyses were carried out.

In the regression analysis for FP, three control variables were entered in the first step (Table III). In congruence with the correlation results, of the three control variables, only stock-listing status of companies positively influenced FP suggesting that the listed firms were financially better of than the nonlisted firms. In the second step of the regression analysis, partialing out the influence of control variables, an increase in aggregate and segregate CSR enhanced the FP of firms.

In the hierarchical regression analysis for NFP, similar to the results of correlation analysis, none of the control variables influenced NFP in the first step (Table IV). But in the second step of the regression analysis, both aggregate and segregate CSR positively influenced the NFP.

Results supported the main hypothesis $\left(\mathrm{H}_{1}\right)$ and its components $\left(\mathrm{H}_{1.1}-\mathrm{H}_{1.6}\right)$. Both aggregate and segregate CSR predicting FP and NFP were significant suggesting that the socially responsible business yielded higher performance of manufacturing firms.

Controlling the confounding effects, aggregate CSR predicted $12 \%$ variance of industry-adjusted ROA (Table III) and 20\% variance of NFP (Table IV). The segregate measures of CSR, incorporating the CSR towards six stakeholder groups, explained from as low as 3\% to as high as $14 \%$ variance of the industry-adjusted ROA and from as low as $7 \%$ to as high as $19 \%$ variance of NFP. First, such findings suggested that listed firms had better CSR and FP than non-listed ones. Second, controlling the confounding effects, both the aggregate and segregate measures of CSR predicted FP and NFP of firms but CSR influenced the NFP of firms more potently compared to FP of firms. Third, the nonexplained variance of FP and NFP suggested that there were other potent explanatory variables beyond the aggregate and segregate measures of CSR and the relations between the explanatory variables and the criterion were not linearly robust. 


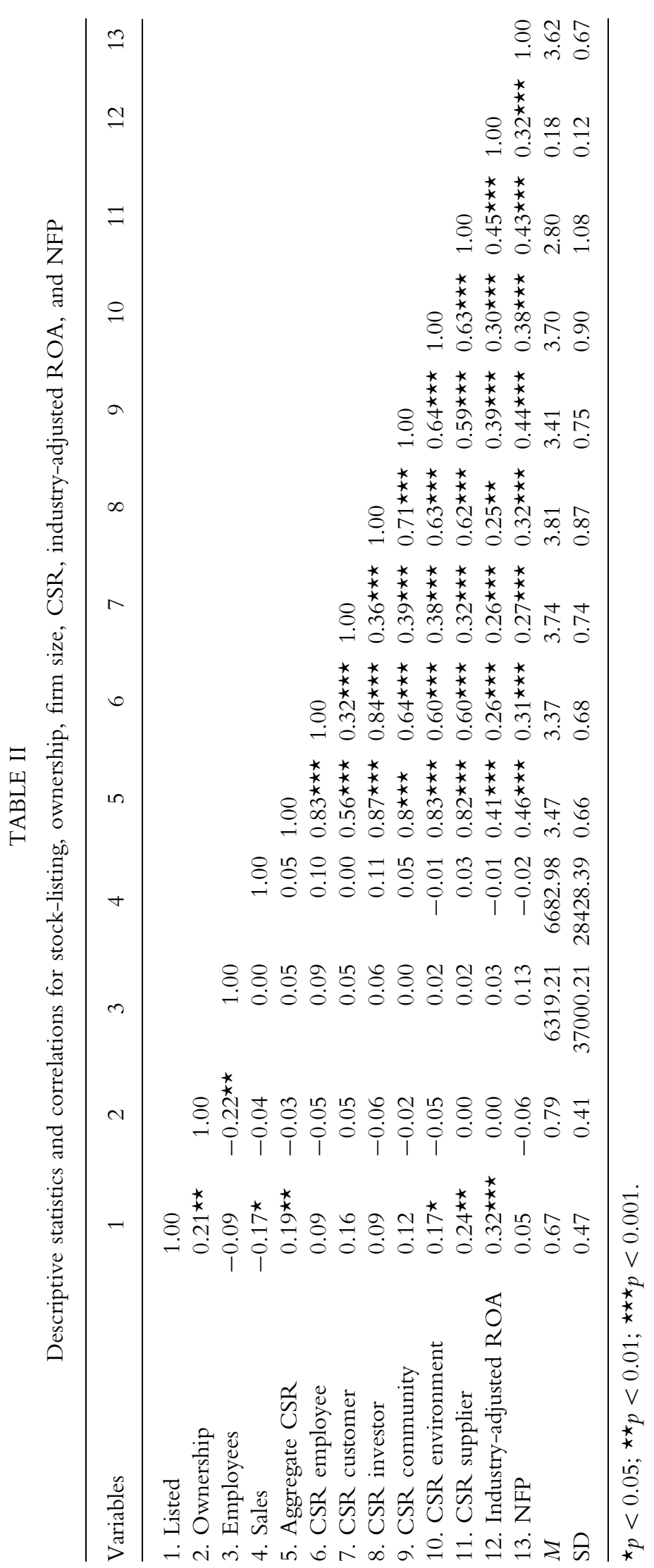


TABLE III

Regression analysis of CSR predicting industry-adjusted ROA

\begin{tabular}{|c|c|c|c|c|c|c|c|c|}
\hline DV & Step & IV & $B$ & SEB & $\mathrm{B}$ & $R^{2}$ & $\Delta R^{2}$ & $F$ \\
\hline \multirow{9}{*}{ Industry-adjusted ROA } & \multirow[t]{4}{*}{1} & Listed & 0.08 & 0.03 & $0.23 \star \star$ & \multirow[t]{4}{*}{0.05} & & \multirow[t]{4}{*}{2.07} \\
\hline & & Ownership & -0.03 & 0.03 & -0.08 & & & \\
\hline & & Employees & 0.00 & 0.00 & 0.03 & & & \\
\hline & & Sales & 0.00 & 0.00 & 0.01 & & & \\
\hline & \multirow[t]{5}{*}{2} & Listed & 0.05 & 0.03 & $0.16^{\star}$ & \multirow[t]{5}{*}{0.17} & \multirow[t]{5}{*}{0.12} & \multirow[t]{5}{*}{$5.96^{\star \star \star}$} \\
\hline & & Ownership & -0.02 & 0.03 & -0.06 & & & \\
\hline & & Employees & 0.00 & 0.00 & 0.02 & & & \\
\hline & & Sales & 0.00 & 0.00 & -0.02 & & & \\
\hline & & Aggregate CSR & 0.09 & 0.02 & $0.35 \star \star \star$ & & & \\
\hline \multirow{9}{*}{ Industry-adjusted ROA } & \multirow[t]{4}{*}{1} & Listed & 0.08 & 0.03 & $0.23 \star \star$ & \multirow[t]{4}{*}{0.05} & & \multirow[t]{4}{*}{2.07} \\
\hline & & Ownership & -0.03 & 0.03 & -0.08 & & & \\
\hline & & Employees & 0.00 & 0.00 & 0.03 & & & \\
\hline & & Sales & 0.00 & 0.00 & 0.01 & & & \\
\hline & \multirow[t]{5}{*}{2} & Listed & 0.07 & 0.03 & $0.20 \star \star$ & \multirow[t]{5}{*}{0.12} & \multirow[t]{5}{*}{0.07} & \multirow[t]{5}{*}{$3.91 \star \star$} \\
\hline & & Ownership & -0.03 & 0.03 & -0.07 & & & \\
\hline & & Employees & 0.00 & 0.00 & 0.01 & & & \\
\hline & & Sales & 0.00 & 0.00 & -0.02 & & & \\
\hline & & CSR-employee & 0.06 & 0.02 & $0.26^{\star \star \star}$ & & & \\
\hline \multirow[t]{9}{*}{ Industry-adjusted ROA } & \multirow[t]{4}{*}{1} & Listed & 0.08 & 0.03 & $0.23 \star \star$ & \multirow[t]{4}{*}{0.05} & & \multirow[t]{4}{*}{2.07} \\
\hline & & Ownership & -0.03 & 0.03 & -0.08 & & & \\
\hline & & Employees & 0.00 & 0.00 & 0.03 & & & \\
\hline & & Sales & 0.00 & 0.00 & 0.01 & & & \\
\hline & \multirow[t]{5}{*}{2} & Listed & 0.07 & 0.03 & $0.21 \star \star$ & \multirow[t]{5}{*}{0.08} & 0.03 & $2.42^{\star}$ \\
\hline & & Ownership & -0.03 & 0.03 & -0.08 & & & \\
\hline & & Employees & 0.00 & 0.00 & 0.02 & & & \\
\hline & & Sales & 0.00 & 0.00 & 0.01 & & & \\
\hline & & CSR-customer & 0.03 & 0.02 & $0.16^{\star}$ & & & \\
\hline Industry-adjusted ROA & 1 & Listed & 0.08 & 0.03 & $0.23 \star \star$ & 0.05 & & 2.07 \\
\hline & & Ownership & -0.03 & 0.03 & -0.08 & & & \\
\hline & & Employees & 0.00 & 0.00 & 0.03 & & & \\
\hline & & Sales & 0.00 & 0.00 & 0.01 & & & \\
\hline & 2 & Listed & 0.07 & 0.03 & $0.20 \star \star$ & 0.11 & 0.06 & $3.47 \star \star$ \\
\hline & & Ownership & -0.03 & 0.03 & -0.06 & & & \\
\hline & & Employees & 0.00 & 0.00 & 0.02 & & & \\
\hline & & Sales & 0.00 & 0.00 & -0.02 & & & \\
\hline & & CSR-investor & 0.04 & 0.01 & $0.24 \star \star$ & & & \\
\hline Industry-adjusted ROA & 1 & Listed & 0.08 & 0.03 & $0.23 \star \star$ & 0.05 & & 2.07 \\
\hline & & Ownership & -0.03 & 0.03 & -0.08 & & & \\
\hline & & Employees & 0.00 & 0.00 & 0.03 & & & \\
\hline & & Sales & 0.00 & 0.00 & 0.01 & & & \\
\hline & 2 & Listed & 0.06 & 0.03 & $0.18^{\star}$ & 0.19 & 0.14 & $6.80^{\star \star \star \star}$ \\
\hline & & Ownership & -0.02 & 0.03 & -0.06 & & & \\
\hline & & Employees & 0.00 & 0.00 & 0.04 & & & \\
\hline & & Sales & 0.00 & 0.00 & -0.01 & & & \\
\hline & & CSR-community & 0.08 & 0.02 & $0.37 \star \star \star$ & & & \\
\hline
\end{tabular}


TABLE III

continued

\begin{tabular}{|c|c|c|c|c|c|c|c|c|}
\hline DV & Step & IV & $B$ & SEB & B & $R^{2}$ & $\Delta R^{2}$ & $F$ \\
\hline \multirow[t]{9}{*}{ Industry-adjusted ROA } & \multirow[t]{4}{*}{1} & Listed & 0.08 & 0.03 & $0.23 \star \star$ & \multirow[t]{4}{*}{0.05} & & \multirow[t]{4}{*}{2.07} \\
\hline & & Ownership & -0.03 & 0.03 & -0.08 & & & \\
\hline & & Employees & 0.00 & 0.00 & 0.03 & & & \\
\hline & & Sales & 0.00 & 0.00 & 0.01 & & & \\
\hline & \multirow[t]{5}{*}{2} & Listed & 0.06 & 0.03 & $0.18^{\star}$ & \multirow[t]{5}{*}{0.15} & \multirow[t]{5}{*}{0.10} & \multirow[t]{5}{*}{$4.89 \star \star \star$} \\
\hline & & Ownership & -0.02 & 0.03 & -0.05 & & & \\
\hline & & Employees & 0.00 & 0.00 & 0.03 & & & \\
\hline & & Sales & 0.00 & 0.00 & 0.01 & & & \\
\hline & & CSR-environment & 0.06 & 0.01 & $0.31 \star \star \star$ & & & \\
\hline \multirow[t]{9}{*}{ Industry-adjusted ROA } & \multirow[t]{4}{*}{1} & Listed & 0.08 & 0.03 & $0.23 \star \star$ & \multirow[t]{4}{*}{0.05} & & \multirow[t]{4}{*}{2.07} \\
\hline & & Ownership & -0.03 & 0.03 & -0.08 & & & \\
\hline & & Employees & 0.00 & 0.00 & 0.03 & & & \\
\hline & & Sales & 0.00 & 0.00 & 0.01 & & & \\
\hline & \multirow[t]{5}{*}{2} & Listed & 0.05 & 0.03 & $0.16^{\star}$ & \multirow[t]{5}{*}{0.14} & \multirow[t]{5}{*}{0.09} & \multirow[t]{5}{*}{$4.81 \star \star \star$} \\
\hline & & Ownership & -0.03 & 0.03 & -0.07 & & & \\
\hline & & Employees & 0.00 & 0.00 & 0.02 & & & \\
\hline & & Sales & 0.00 & 0.00 & -0.01 & & & \\
\hline & & CSR-supplier & 0.05 & 0.01 & $0.31 \star \star \star$ & & & \\
\hline
\end{tabular}

$D V$ dependent variable, $I V$ independent variable, $B$ beta, $S E B$ standard error of beta, $\beta$ standardized beta, $R^{2}$ coefficient of determination.

$\star_{p}<0.05 ;{ }^{\star \star} p<0.01 ; \star \star \star p<0.001$.

\section{Discussion}

Analyzing the data from 150 Indian companies, the study examines the influence of CSR on financial and non-financial firm performance. CSR was assessed with respect to six primary stakeholders as well as with respect to the aggregation of all stakeholders. Results show that firms that are listed in stock exchanges have better CSR and FP, but neither the ownership pattern nor firm size has influenced CSR, FP, and NFP. Controlling the confounding effects of stock-listing status, ownership pattern, and firm size, an increase in the aggregate measure of CSR has increased the FP and NFP of firms. Also, more favorable CSR towards each of the stakeholders has increased firm performance.

Stock-listing, ownership, firm size, and CSR

A favorable influence of stock-listing status on CSR establishes that listed firms whose performance is monitored regularly by multiple stakeholders display a higher level of CSR compared to the non-listed firms. Due to such monitoring and exposure to multiple stakeholders, listed firms perform financially better than the non-listed ones. Performance of the listed firms is shown in the balance sheets through the measures of FP. Hence, stock-listing influences FP of firms. However, it does not influence NFP which is a subjective measure and is not captured in balance sheets for evaluation by multiple stakeholders. Lack of influence of ownership and firm size on CSR and firm performance establishes that there is no difference between the SOEs and private sector companies in India with respect to the level of CSR displayed by them. Private sector companies such as Tata Steel and Apollo Tyres are as responsible as the SOEs such as Rastriya Ispat Nigam Limited and Gas Authority of India Limited. Furthermore, larger firms do not always display a high level of CSR compared to the smaller firms (Wu, 2006). Smaller firms like Orissa Milk Federation are as sensitive to stakeholders as larger firms in the same category like AMUL. 
TABLE IV

Regression analysis of CSR predicting NFP

\begin{tabular}{|c|c|c|c|c|c|c|c|c|}
\hline DV & Step & IV & $B$ & SEB & $\beta$ & $R^{2}$ & $\Delta R^{2}$ & $F$ \\
\hline \multirow[t]{9}{*}{ NFP } & \multirow[t]{4}{*}{1} & Listed & 0.09 & 0.12 & 0.07 & \multirow[t]{4}{*}{0.02} & & \multirow[t]{4}{*}{0.84} \\
\hline & & Ownership & -0.08 & 0.14 & -0.05 & & & \\
\hline & & Employees & 0.00 & 0.00 & 0.13 & & & \\
\hline & & Sales & 0.00 & 0.00 & -0.01 & & & \\
\hline & \multirow[t]{5}{*}{2} & Listed & -0.05 & 0.11 & -0.03 & \multirow[t]{5}{*}{0.22} & \multirow[t]{5}{*}{0.20} & \multirow[t]{5}{*}{$8.35^{\star \star \star}$} \\
\hline & & Ownership & -0.04 & 0.13 & -0.02 & & & \\
\hline & & Employees & 0.00 & 0.00 & 0.10 & & & \\
\hline & & Sales & 0.00 & 0.00 & -0.05 & & & \\
\hline & & Aggregate CSR & 0.47 & 0.08 & $0.46 \star \star \star$ & & & \\
\hline \multirow[t]{9}{*}{ NFP } & \multirow[t]{4}{*}{1} & Listed & 0.09 & 0.12 & 0.07 & \multirow{4}{*}{0.02} & & \multirow[t]{4}{*}{0.84} \\
\hline & & Ownership & -0.08 & 0.14 & -0.05 & & & \\
\hline & & Employees & 0.00 & 0.00 & 0.13 & & & \\
\hline & & Sales & 0.00 & 0.00 & -0.01 & & & \\
\hline & \multirow[t]{5}{*}{2} & Listed & 0.04 & 0.12 & 0.03 & \multirow{5}{*}{0.11} & \multirow{5}{*}{0.09} & \multirow{5}{*}{$3.59 \star \star$} \\
\hline & & Ownership & -0.06 & 0.14 & -0.03 & & & \\
\hline & & Employees & 0.00 & 0.00 & 0.10 & & & \\
\hline & & Sales & 0.00 & 0.00 & -0.04 & & & \\
\hline & & CSR-employee & 0.30 & 0.08 & $0.30 \star \star \star$ & & & \\
\hline \multirow[t]{9}{*}{ NFP } & \multirow[t]{4}{*}{1} & Listed & 0.09 & 0.12 & 0.07 & \multirow[t]{4}{*}{0.02} & & \multirow[t]{4}{*}{0.84} \\
\hline & & Ownership & -0.08 & 0.14 & -0.05 & & & \\
\hline & & Employees & 0.00 & 0.00 & 0.13 & & & \\
\hline & & Sales & 0.00 & 0.00 & -0.01 & & & \\
\hline & \multirow[t]{5}{*}{2} & Listed & 0.03 & 0.12 & 0.02 & \multirow[t]{5}{*}{0.09} & 0.07 & $2.89^{\star}$ \\
\hline & & Ownership & -0.10 & 0.14 & -0.06 & & & \\
\hline & & Employees & 0.00 & 0.00 & 0.11 & & & \\
\hline & & Sales & 0.00 & 0.00 & -0.01 & & & \\
\hline & & CSR-customer & 0.24 & 0.07 & $0.27 \star \star \star$ & & & \\
\hline NFP & 1 & Listed & 0.09 & 0.12 & 0.07 & 0.02 & & 0.84 \\
\hline & & Ownership & -0.08 & 0.14 & -0.05 & & & \\
\hline & & Employees & 0.00 & 0.00 & 0.13 & & & \\
\hline & & Sales & 0.00 & 0.00 & -0.01 & & & \\
\hline & 2 & Listed & 0.04 & 0.12 & 0.03 & 0.12 & 0.10 & $3.83^{\star \star}$ \\
\hline & & Ownership & -0.05 & 0.14 & -0.03 & & & \\
\hline & & Employees & 0.00 & 0.00 & 0.11 & & & \\
\hline & & Sales & 0.00 & 0.00 & -0.05 & & & \\
\hline & & CSR-investor & 0.24 & 0.06 & $0.31 \star \star \star \star$ & & & \\
\hline NFP & 1 & Listed & 0.09 & 0.12 & 0.07 & 0.02 & & 0.84 \\
\hline & & Ownership & -0.08 & 0.14 & -0.05 & & & \\
\hline & & Employees & 0.00 & 0.00 & 0.13 & & & \\
\hline & & Sales & 0.00 & 0.00 & -0.01 & & & \\
\hline & 2 & Listed & 0.01 & 0.11 & 0.00 & 0.21 & 0.19 & $7.74 \star \star \star$ \\
\hline & & Ownership & -0.05 & 0.13 & -0.03 & & & \\
\hline & & Employees & 0.00 & 0.00 & 0.13 & & & \\
\hline & & Sales & 0.00 & 0.00 & -0.04 & & & \\
\hline & & CSR-community & 0.40 & 0.07 & $0.44 \star \star \star$ & & & \\
\hline
\end{tabular}


TABLE IV

continued

\begin{tabular}{|c|c|c|c|c|c|c|c|c|}
\hline DV & Step & IV & $B$ & SEB & $\beta$ & $R^{2}$ & $\Delta R^{2}$ & $F$ \\
\hline \multirow[t]{9}{*}{ NFP } & \multirow[t]{4}{*}{1} & Listed & 0.09 & 0.12 & 0.07 & \multirow[t]{4}{*}{0.02} & & \multirow[t]{4}{*}{0.84} \\
\hline & & Ownership & -0.08 & 0.14 & -0.05 & & & \\
\hline & & Employees & 0.00 & 0.00 & 0.13 & & & \\
\hline & & Sales & 0.00 & 0.00 & -0.01 & & & \\
\hline & \multirow[t]{5}{*}{2} & Listed & -0.01 & 0.12 & 0.00 & \multirow[t]{5}{*}{0.16} & \multirow[t]{5}{*}{0.14} & \multirow[t]{5}{*}{$5.39 \star \star \star$} \\
\hline & & Ownership & -0.03 & 0.13 & -0.02 & & & \\
\hline & & Employees & 0.00 & 0.00 & 0.12 & & & \\
\hline & & Sales & 0.00 & 0.00 & -0.01 & & & \\
\hline & & CSR-environment & 0.28 & 0.06 & $0.37 \star \star \star$ & & & \\
\hline \multirow[t]{9}{*}{ NFP } & \multirow[t]{4}{*}{1} & Listed & 0.09 & 0.12 & 0.07 & \multirow[t]{4}{*}{0.02} & & \multirow[t]{4}{*}{0.84} \\
\hline & & Ownership & -0.08 & 0.14 & -0.05 & & & \\
\hline & & Employees & 0.00 & 0.00 & 0.13 & & & \\
\hline & & Sales & 0.00 & 0.00 & -0.01 & & & \\
\hline & \multirow[t]{5}{*}{2} & Listed & -0.07 & 0.11 & -0.05 & \multirow[t]{5}{*}{0.21} & \multirow[t]{5}{*}{0.19} & \multirow[t]{5}{*}{$7.55^{\star \star \star}$} \\
\hline & & Ownership & -0.05 & 0.13 & -0.03 & & & \\
\hline & & Employees & 0.00 & 0.00 & 0.11 & & & \\
\hline & & Sales & 0.00 & 0.00 & -0.04 & & & \\
\hline & & CSR-supplier & 0.28 & 0.05 & $0.44 \star \star \star$ & & & \\
\hline
\end{tabular}

$D V$ dependent variable, $I V$ independent variable, $B$ beta, $S E B$ standard error of beta, $\beta$ standardized beta, $R^{2}$ coefficient of determination.

$\star_{p}<0.05 ;{ }^{\star \star} p<0.01 ; \star \star \star p<0.001$

\section{Aggregate CSR and firm performance}

An increase in the aggregate CSR boosts firm performance. CSR-related benefits may arise due to two reasons. First, the CSR-induced revenue can increase from enhanced sales and prices/margins. Second, the CSR-induced cost decrease can result from tax concessions, reductions of duties by the government to promote CSR activities, efficiency gains from environment-friendly technologies, and reduced cost of capital. A stakeholder-oriented firm while generating value for its stakeholders also generates value for its shareholders. A favorable aggregate CSR towards all the primary stakeholders creates a fleet of satisfied stakeholders who bring in efficiency gains and cost advantages through various means that ultimately improve firm performance. Satisfied employees reward the firm through productivity gains and reduced hiring and training costs, satisfied customers improve product sales through repeat purchase behavior, satisfied investors lend more capital at a cheaper rate decreasing cost of capital, satisfied communities reduce the public relations cost, environmental stewardship leads to reputational advantages, and better suppliers reduce quality certification costs. Findings establish that effective management of key stakeholders improves FP (Berman et al., 1999; Waddock and Graves, 1997). By being responsive to stakeholders, a firm also ensures superior performance compared to its competitors (Turban and Greening, 1997). When firms enhance CSR towards their stakeholders, consumers not only like, respect, or admire the firms but also identify with it. Such identification becomes so strong and enduring (Sen and Bhattacharya, 2001) that consumers become brand ambassadors of the firms (Springer, 2006) with long-lasting loyalty (Gillentine, 2006).

\section{CSR towards employees and firm performance}

Past research establishes the importance of primary stakeholders as value drivers of a firm's performance 
(Barney and Hansen, 1994; Clarkson, 1995; Fomburn and Shanley, 1990). A direct link between CSR towards employees and firm performance substantiates previous findings (Berman et al., 1999). Higher CSR towards employees in terms of employee-sensitive policies and practices by firms enhances employee productivity, reduces absenteeism, and facilitates recruitment and retention of better quality employees (Turban and Greening, 1997). Attention on progressive human resource management practices, including training and development of employees, their participation in problem solving, progressive remuneration policies, and grievance handling reduces the attrition rate, increases employee productivity and FP (Huselid, 1995; Youndt et al., 1996). Lower attrition rates lead to lesser personnel hiring costs that ultimately improve firm performance. Corroborating past findings (Leff, 2004), the study finds that concern for employees is a part of core activities of Indian companies that improves firm performance. Indian companies have successfully integrated various CSR issues related to employees such as workplace safety and benefit plans into the companies' functions that ultimately reward them by enhancing their profitability and competitive position. Better corporate consciousness on these issues and positive influence of CSR towards employees on firm performance may be attributed to the presence of empowered trade unions and strong labor laws in India, particularly in case of manufacturing companies.

\section{CSR towards customers and firm performance}

A favorable CSR towards customers enhances firm profitability and NFP. This is congruent with previous findings that firms gain by adding socially responsible elements to products (Berman et al., 1999; Bromiley and Marcus, 1989; Davidson and Worell, 1988). Ceteris paribus, customers are more likely to buy from companies that engage in CSR activities that they find appropriate and personally relevant (Brown and Dacin, 1997; Sen et al., 2006). Customers reward companies that produce reliable and better quality products, and adhere to safety standards which improve FP (Berman et al., 1999; Graafland and van de Ven, 2006). Company policies and practices towards issues such as ethical advertising and pricing or providing products to the economic dis- advantaged induce a 'feel good factor' among the customers. They feel happy and proud to be identified with such companies. Such identification (Sen and Bhattacharya, 2001) elicits repeat purchase behavior and ushers in competitive advantage for the firm. Alternatively, customers boycott companies who mislead them. An independent survey by GMI Poll (2005) finds that Nestle is one of the most widely boycotted companies in the world for its unethical promotion of baby foods and infant formulas. Companies such as Nestlé India, Johnson and Johnson, and Wockhardt that sell baby foods are being prosecuted in India for giving misleading and scientifically incorrect information on infant feeding in their advertisements and promotion materials (Gupta, 2005). Boycotting of a company's products and agitations and legal actions against the company jeopardize its image and adversely affect firm performance (Berman et al., 1999; Financial Express, 2006).

\section{CSR towards investors and firm performance}

Past research has established that better governance standards of companies lead to enhanced profitability (Black and Khanna, 2007; Business Week, 2002). Better corporate governance practices by firms have favorable impact on FP indicators such as economic value added and market value added (Coles et al., 2001). Commitment of the management towards strong controls emphasizing ethical and social responsible behavior improves profitability (Verschoor, 1998) and acts as a source of competitive advantage for firms. Stakeholders have increased confidence on such firms. Investors pay a premium to buy the stocks of well-governed firms (Coombes and Watson, 2000). They even become willing to provide further capital to such firms at a lower rate of interest which reduces the cost of capital. Such factors enhance firm value and performance. Indian companies have to comply with various mandatory governance standards laid down in the Clause 49 of the Listing Agreements, 2005 which is implemented by SEBI. Companies that fail to comply with the standards have the risk of getting delisted from Indian stock exchanges. This has made many Indian companies proactive in adopting corporate governance standards. Moreover, success of companies such as Infosys due to adoption of better corporate governance 
standards has motivated many other Indian firms to display similar practices and reap benefits of good governance (CLSA, 2000).

\section{CSR towards community and firm performance}

Qualitative research on CSR using case studies establishes a favorable relation between community initiatives of firms and improved firm performance (Brugmann and Prahalad, 2007; Rockefeller, 2003) though empirical research (Berman et al., 1999) does not find a significant relation between the two constructs. Findings of this study corroborate the findings of the qualitative research. A recent survey on business-community relations in India shows that $85 \%$ of the surveyed firms agree that they have a responsibility to the surrounding community and are committed towards their cause (Mahajan, 2004). A socially responsible image of companies among the local community improves the brand and loyalty of consumers. Consumers reward good corporate citizens through greater and sustained patronage (Luo and Bhattacharya, 2006). Positive CSR of companies enhances overall product evaluation by consumers (Brown and Dacin, 1997). Consumers pay attention to the CSR records of the companies, encompassing mainly their community initiatives, while purchasing (Gildea, 1994; Owen and Scherer, 1993). Good corporate citizens can also reduce costs through indirect benefits such as tax advantages, improved quality of local labor, and fewer lawsuits from employees and environmentalists (Ullman, 1985; Waddock and Graves, 1997). Section 80G of the Income Tax Act in India grants tax benefits to Indian companies that invest on community development projects. Investment in such projects in association with the local government and NGOs improves the firm's image while reducing its expenses on tax payments. The firm faces less resistance from the local community and the government while pursuing its activities. The Tata group, which is well known as the most respected corporate citizen in India, provides the cheapest car in the world to the burgeoning cash-starving middleincome Indian families through its 'Nano' project. This project has received support from local governments and community in many Indian states due to the company's reputation of corporate citizenship.

\section{CSR towards environment and firm performance}

A favorable CSR towards environment increasing FP and NFP of firms supports past findings (Ahmed et al., 1998; Alvarez et al., 2001). Environmentally compatible products, processes and management systems enhance profitability either through revenue gains or through cost savings. Revenues increase as consumers prefer products of environmentally proactive companies (Owen and Scherer, 1993; Rosewicz, 1990). Investment in environmental management systems reduces costs arising from environmental crisis, wastages of raw materials, and inefficient production processes (Allen, 1992; Schmidheiny, 1992). Market values of firms significantly increase when they adopt environmentally proactive stands or receive environmental awards (Klassen and Mc Laughlin, 1996). Adoption of superior environmental standards not only prepares firms to handle stricter regulations in the future but also positions them ahead of competitors (Barrett, 1992). Mainly four factors can be attributed to the environmental proactivity of Indian companies. First, there is a separate ministry under the Indian government, the ministry of environment and forest, which monitors and enforces environmental quality standards through pollution control boards. Companies are required to adhere to mandatory standards specified in over 180 enactments related to environmental and industrial pollution such as the Forest (Conservation) Act, 1981, the Air (Prevention and Control of Pollution) Act, 1986, and the Environment (Prevention) Act, 1986. Second, since 1994, environmental management plans have been made mandatory for setting up new business units, and expansion or modernization of existing units. Third, past industrial disasters like the 'Bhopal Gas tragedy' in 1984 have raised environmental consciousness of Indian companies. Fourth, adoption of voluntary environmental standards has become a prerequisite to compete in the global market. Such factors have prompted Indian companies to include environmental management practices as a part of their core activities (Leff, 2004). Among the 150 studied firms, 92\% have clearance from pollution control boards, which is mandatory. In addition, 43\% have adopted ISO 14000 and 15\% have adopted OHSAS 18000. Such proactivity enhances firm performance. 
CSR towards suppliers and firm performance

The demand for social audit by international buyers and multi-national business associates from developed countries has made it necessary for companies in emerging markets like India to ensure responsible and ethical practices at suppliers' locations. By ensuring ethical practices at suppliers' locations, companies increase their competitiveness and image in the global market that improves firm performance. The findings of the study concur that favorable CSR towards suppliers can be a definite source of competitive advantage and bring higher returns.

\section{Limitations}

There are certain limitations of the study that must be acknowledged. First, the data on CSR and NFP are perceptual in nature. Respondents might have overemphasized the positive aspects of CSR as well as NFP of their firms and understated corresponding negative aspects. Notwithstanding the limitations, a priori model is assumed for the items measuring each construct of CSR and ascertained applying CFA that arrests the common method variance statistically. Moreover, because the data on FP and CSR are collected from two different sources, common method variance in the results is also arrested procedurally (Podsakoff et al., 2003). Second, the data are collected from 18 categories of industries. Issues faced by each category being unique and different from one another, an aggregate analysis across multiple categories of industries might have missed industry-specific issues (Griffin and Mahon, 1997). However, CSR issues included in the study are generic in nature. For example, product quality and price, safety standards in the work place, community partnership, or stronger governance standards represent responsible business practices across industries. Third, the proposed CSR measure may be a narrow conceptualization of CSR as it assesses a firm's social policies and practices towards primary stakeholders. The measure can be strengthened by incorporating actionable outcomes. For example, items like policies and practices towards 'training and development of women and minorities' or 'sexual harassment prohibition' can be matched with corresponding actionable outcomes about the actual number of training programs provided to women and minorities or the redressal of actual number of sexual harassment cases. Lastly, because data are collected from only 18 categories of manufacturing industries in India, caution must be exercised in generalizing the findings.

\section{Implications and future research direction}

Corporate social responsibility (policy, program, or process) is 'strategic' when it yields substantial business-related benefits to the firm (Burke and Logsdon, 1996). This approach towards CSR has been criticized by researchers for a lack of intrinsic and moral grounding (Margolis and Walsh, 2003; Vogel, 2005). They argue that such an approach reduces CSR to a marketing instrument (Maignan and Ferrell, 2001) and turns stakeholders as 'means' to the 'ends' of maximizing shareholder wealth (Goodpaster, 1998). This research adds a 'stakeholder-sense' to the 'business-sense' of CSR. By designing stakeholdersensitive policies, firms cater to a wide range of issues relevant to stakeholders. Many issues included in the proposed CSR framework do not have a direct link with profitability. For example, indicators such as ethical advertising, diversity, policies towards insider trading, or policies to eliminate human rights' abuses at the work place and supplier locations do not have any direct financial implications. Rather these factors bring ethical issues into the CSR discussion. In this sense, this study addresses the concern about lack of ethical dimensions in CSR research. By bringing stakeholder-sensitive and ethical issues into the CSR framework, it advocates such an approach can be beneficial for both the firm and its stakeholders, and lead to a win-win situation for both.

This study contributes to the empirical literature of CSR in three ways. First, when the study was carried out in 2005, no systematic database on CSR was available for evaluating Indian companies from the stakeholders' perspective. Though there are few recent attempts to rate CSR activities of Indian companies, like the Karmayog CSR rating (IndiaPR wire.com, 2007), an objective assessment of CSR like that done by KLD in the US is still not found in India. We have developed and validated an instrument to assess CSR from the stakeholders' perspective in the Indian context that can be used in 
future investigations. Second, past studies (Cochran and Wood, 1984; Ruf et al., 2001; Waddock and Graves, 1997) have used aggregate CSR measures from secondary sources due to the availability of such data. This study has considered a segregated form of CSR in addition to the aggregated form in the analysis by collecting primary data on individual CSR dimensions of firms. A segregated analysis of CSR points out critical issues embedded in specific stakeholders and the influence of such issues on firm performance, which cannot be captured by carrying out an aggregated analysis alone. Capturing such issues are important because, influenced by a higher level of aggregate CSR, companies may overlook specific stakeholder issues which might have critical bearing on firm performance. Third, few studies have reported the positive impact of environmental proactivity on NFP (Ahmed et al., 1998; Benito and Benito, 2005) but not in the context of other stakeholders. This study reveals the direct influence of CSR towards six primary stakeholder groups including environment on NFP as well as on FP. Convergence of results from the two analyses, one using FP and the other using NFP, strengthens the link (Bouchard, 1976) between CSR and firm performance. Contrary to negative relationships found in few past studies (Davidson and Worell, 1988; Davidson et al., 1987), this study establishes positive relationships between the aggregate and segregate dimensions of CSR and firm performance. The negative results of past studies are mostly attributed to the use of volatile market-based measures such as stock returns (Griffin and Mahon, 1997). Because this study has used a more consistent accounting measure of ROA, the results concur with past positive evidences on CSR influencing firm performance (Graves and Waddock, 1994; Griffin and Mahon, 1997; McGuire et al., 1988). Furthermore, it is important to account for the contribution of CSR towards the creation of intangible assets such as corporate reputation and image which are reflected in a firm's NFP. This study reports CSR as a better predictor of NFP compared to FP. The aggregate and segregate dimensions of CSR are found to be the more potent contributors to creation of intangible assets such as employee satisfaction, customer relationships, and internal business process efficiency, compared to the tangible financial gains.
During the survey, it was found that many Indian executives had misconceptions about CSR. Many companies initially declined to participate in the survey on the ground that they did not have a CSR department or did not undertake any CSR activity. Like a recent survey which finds that CSR activities of many Indian companies are mainly handled by public relations or human resources department rather than a CSR department (Sagar and Singla, 2004), our survey also finds that $90 \%$ of the surveyed companies have neither an exclusive department nor a specific budget for CSR. Moreover, surveyed managers equated CSR with philanthropic activities such as conducting health awareness programs, plantation activities, and donating for charity or socio-cultural activities. They participated in the survey when it was explained that a proper assessment of CSR goes beyond philanthropy and includes responsible business behaviors towards stakeholders. This suggests that though Indian companies adopt stakeholder sensitive policies and practices, they are not aware that such activities could be called CSR. This study can be an eyeopener for Indian executives for broadening their understanding of CSR that includes the stakeholder map. Moreover, this study addresses the concern of Indian businessmen who do not adopt a long-term CSR policy due to its lack of provable link with profitability (British Council et al., 2002). The present findings may translate into higher number of Indian companies engaging in meaningful CSR activities emphasizing stakeholder relations. The study is conducted in the manufacturing sector. Future study may be carried out for specific industry categories even within the manufacturing industry such as automobile, chemical, and the like to bring out industry specific issues. Future research may also deal with CSR issues in the service sector and the small and medium enterprises which are growing at a faster rate in India. This study has not considered the influence of price on CSR strategy. Studying consumers' reactions when CSR costs are added to the price of a product can be a potential area of research in the context of the price sensitive Indian consumers. Influence of Indian values and leadership style on the managerial approach towards CSR can also be investigated. 


\section{Notes}

1 Kisan Kendra is the Hindi name for 'farmer centre'.

2 English meaning of Subh Labh is 'auspicious profit', a word often used by Indian business men.

\section{Appendix}

See Table V.

TABLE V

Scale items and validity

\begin{tabular}{|c|c|c|c|c|c|c|c|c|}
\hline Variable & No. of items & GFI & CFI & NFI & RMSEA & USRW & SE & SRW \\
\hline 1. CSR employee & 13 & 0.8 & 0.62 & 0.56 & 0.14 & & & \\
\hline $\begin{array}{l}\text { 1.1 An equal opportunity } \\
\text { action plan }\end{array}$ & & & & & & 1.00 & & $0.64 \star \star \star$ \\
\hline $\begin{array}{l}\text { 1.2 Anti-discrimination poli- } \\
\text { cies towards issues of gender, } \\
\text { pregnancy, marital status }\end{array}$ & & & & & & 1.50 & 0.28 & $0.82^{\star \star \star}$ \\
\hline $\begin{array}{l}\text { 1.3 Policies towards sexual } \\
\text { harassment prohibition }\end{array}$ & & & & & & 1.53 & 0.38 & $0.80 \star \star \star$ \\
\hline $\begin{array}{l}\text { 1.4 Policies towards disability/ } \\
\text { disability harassment prohibi- } \\
\text { tion }\end{array}$ & & & & & & 1.32 & 0.39 & $0.69 \star \star \star$ \\
\hline $\begin{array}{l}\text { 1.5 Policies to ensure repre- } \\
\text { sentation of women and } \\
\text { minorities in the Board of } \\
\text { Directors }\end{array}$ & & & & & & 0.14 & 0.36 & $0.16^{\dagger}$ \\
\hline $\begin{array}{l}1.6 \text { Compensation of workers } \\
\text { as per legally mandated mini- } \\
\text { mum wages }\end{array}$ & & & & & & 0.08 & 0.1 & 0.13 \\
\hline $\begin{array}{l}\text { 1.7 Policies towards prohibit- } \\
\text { ing forced overtime }\end{array}$ & & & & & & 0.04 & 0.07 & 0.02 \\
\hline $\begin{array}{l}\text { 1.8 Policies for the training } \\
\text { and development of } \\
\text { employees }\end{array}$ & & & & & & 0.00 & 0.20 & 0.00 \\
\hline $\begin{array}{l}\text { 1.9 Special staff development } \\
\text { opportunities for women and } \\
\text { minorities }\end{array}$ & & & & & & 0.55 & 0.11 & $0.37 \star \star \star$ \\
\hline $\begin{array}{l}\text { 1.10 Promotion policy for } \\
\text { women and minorities }\end{array}$ & & & & & & 0.62 & 0.21 & $0.39 \star \star \star$ \\
\hline $\begin{array}{l}\text { 1.11 The right to freedom of } \\
\text { association, collective bar- } \\
\text { gaining and complaint proce- } \\
\text { dure }\end{array}$ & & & & & & 0.32 & 0.23 & $0.27 \star \star \star$ \\
\hline $\begin{array}{l}1.12 \text { Policies covering health } \\
\text { and safety at work }\end{array}$ & & & & & & 0.18 & 0.16 & $0.26^{\star \star \star}$ \\
\hline $\begin{array}{l}1.13 \text { Provision for formal } \\
\text { worker representation in } \\
\text { decision-making }\end{array}$ & & & & & & 0.74 & 0.09 & $0.45^{\star \star \star}$ \\
\hline
\end{tabular}


TABLE V

continued

\begin{tabular}{|c|c|c|c|c|c|c|c|c|}
\hline Variable & No. of items & GFI & CFI & NFI & RMSEA & USRW & SE & SRW \\
\hline 2. CSR customer & 7 & 0.93 & 0.81 & 0.76 & 0.12 & & & \\
\hline $\begin{array}{l}2.1 \text { Competitive prices and } \\
\text { payment conditions for prod- } \\
\text { ucts commensurate with } \\
\text { quality }\end{array}$ & & & & & & 1.00 & & $0.52^{\star \star \star}$ \\
\hline $\begin{array}{l}2.2 \text { Policy/management sys- } \\
\text { tems for customer satisfaction }\end{array}$ & & & & & & 1.68 & 0.35 & $0.69 \star \star \star$ \\
\hline $\begin{array}{l}2.3 \text { Policy/management sys- } \\
\text { tems for preserving customer } \\
\text { health and safety during use of } \\
\text { products }\end{array}$ & & & & & & 2.02 & 0.49 & $0.49 \star \star \star$ \\
\hline $\begin{array}{l}\text { 2.4 Standards and voluntary } \\
\text { codes for advertising }\end{array}$ & & & & & & 2.03 & 0.54 & $0.43 \star \star \star$ \\
\hline $\begin{array}{l}2.5 \text { Commitment to quality } \\
\text { through a well-developed, } \\
\text { company-wide quality pro- } \\
\text { gram }\end{array}$ & & & & & & 1.63 & 0.36 & $0.59 \star \star \star$ \\
\hline $\begin{array}{l}\text { 2.6 Commitment to industry } \\
\text { research and development and } \\
\text { innovation }\end{array}$ & & & & & & 1.24 & 0.34 & $0.41^{\star \star \star}$ \\
\hline $\begin{array}{l}\text { 2.7 Direct involvement in } \\
\text { providing products to the } \\
\text { economically disadvantaged }\end{array}$ & & & & & & 1.47 & 0.44 & $0.37 \star \star \star$ \\
\hline 3. CSR investor & 7 & 0.95 & 0.9 & 0.84 & 0.09 & & & \\
\hline $\begin{array}{l}\text { 3.1 Constitutional reference } \\
\text { for shareholders' participation } \\
\text { in decision making and access } \\
\text { to all relevant information }\end{array}$ & & & & & & 1.00 & & $0.44 \star \star \star$ \\
\hline $\begin{array}{l}\text { 3.2 Provision of all required } \\
\text { information to credit rating } \\
\text { agencies }\end{array}$ & & & & & & 1.70 & 0.39 & $0.63 \star \star \star$ \\
\hline $\begin{array}{l}\text { 3.3 Investor grievances han- } \\
\text { dling policies }\end{array}$ & & & & & & 1.55 & 0.34 & $0.73 \star \star \star$ \\
\hline $\begin{array}{l}\text { 3.4 Rules to strengthen audi- } \\
\text { tor independence }\end{array}$ & & & & & & 0.80 & 0.20 & $0.53 \star \star \star$ \\
\hline $\begin{array}{l}3.5 \text { Regulatory mechanisms } \\
\text { for prohibiting insider trading }\end{array}$ & & & & & & 1.42 & 0.36 & $0.50 \star \star \star$ \\
\hline $\begin{array}{l}\text { 3.6 Commitment to reporting } \\
\text { on financial and non-financial } \\
\text { issues }\end{array}$ & & & & & & 1.13 & 0.30 & $0.47 \star \star \star$ \\
\hline $\begin{array}{l}\text { 3.7 Policies and procedures } \\
\text { for engaging in wide range of } \\
\text { stakeholder-dialogs }\end{array}$ & & & & & & 0.96 & 0.29 & $0.38 \star \star \star$ \\
\hline 4. CSR community & 12 & 0.84 & 0.77 & 0.67 & 0.11 & & & \\
\hline $\begin{array}{l}\text { 4.1 Policy for contribution of } \\
\text { skills and time of employees } \\
\text { for community services }\end{array}$ & & & & & & 1.00 & & $0.49 \star \star \star$ \\
\hline
\end{tabular}




\section{TABLE V}

continued

\begin{tabular}{|c|c|c|c|c|c|c|c|c|}
\hline Variable & No. of items & GFI & CFI & NFI & RMSEA & USRW & SE & SRW \\
\hline $\begin{array}{l}4.2 \text { Observes, both directly } \\
\text { and indirectly, all relevant } \\
\text { local laws and regulations }\end{array}$ & & & & & & 0.28 & 0.07 & $0.43 \star \star \star$ \\
\hline $\begin{array}{l}4.3 \text { Helps community } \\
\text { through charitable donations, } \\
\text { and educational and cultural } \\
\text { contributions }\end{array}$ & & & & & & 0.95 & 0.18 & $0.64 \star \star \star$ \\
\hline $\begin{array}{l}\text { 4.4 Supports for third party } \\
\text { social and sustainable devel- } \\
\text { opment related initiatives }\end{array}$ & & & & & & 1.35 & 0.25 & $0.68^{\star \star \star}$ \\
\hline $\begin{array}{l}\text { 4.5 Supports educational pro- } \\
\text { grams for the promotion of } \\
\text { corporate citizenship }\end{array}$ & & & & & & 1.62 & 0.29 & $0.75^{\star \star \star}$ \\
\hline $\begin{array}{l}\text { 4.6 Supports public policies } \\
\text { and practices to promote } \\
\text { human development and } \\
\text { democracy }\end{array}$ & & & & & & 1.25 & 0.25 & $0.60 \star \star \star$ \\
\hline $\begin{array}{l}\text { 4.7 Pursues partnerships with } \\
\text { community organizations, } \\
\text { government agencies and } \\
\text { other industry groups dedi- } \\
\text { cated to social causes }\end{array}$ & & & & & & 1.48 & 0.26 & $0.77 \star \star \star$ \\
\hline $\begin{array}{l}4.8 \text { Prohibits child labor, and } \\
\text { violation of human rights }\end{array}$ & & & & & & 0.22 & 0.08 & $0.27 \star \star$ \\
\hline $\begin{array}{l}4.9 \text { Makes timely payment of } \\
\text { taxes }\end{array}$ & & & & & & 0.13 & 0.10 & 0.11 \\
\hline $\begin{array}{l}\text { 4.10 Policy for dealing with a } \\
\text { country that systematically } \\
\text { violates human rights }\end{array}$ & & & & & & 0.65 & 0.20 & $0.31 \star \star \star$ \\
\hline $\begin{array}{l}4.11 \text { Policy for social } \\
\text { accountability or sustainable } \\
\text { reporting }\end{array}$ & & & & & & 1.05 & 0.24 & $0.47 \star \star \star$ \\
\hline $\begin{array}{l}4.12 \text { Code of conduct with } \\
\text { regard to bribery, gift receipts } \\
\text { and corruption }\end{array}$ & & & & & & 0.10 & 0.21 & 0.05 \\
\hline 5. CSR environment & 17 & 0.66 & 0.66 & 0.61 & 0.16 & & & \\
\hline $\begin{array}{l}5.1 \text { Explicit definition of } \\
\text { environmental policy and } \\
\text { long term environmental } \\
\text { plans }\end{array}$ & & & & & & 1.00 & 0.13 & $0.69 \star \star \star$ \\
\hline $\begin{array}{l}5.2 \mathrm{Well} \text { defined environment } \\
\text { responsibilities }\end{array}$ & & & & & & 1.02 & 0.13 & $0.70^{\star \star \star}$ \\
\hline $\begin{array}{l}5.3 \text { Systems for measuring and } \\
\text { assessing environmental } \\
\text { performance }\end{array}$ & & & & & & 0.92 & 0.13 & $0.60^{\star \star \star}$ \\
\hline
\end{tabular}


TABLE V

continued

\begin{tabular}{|c|c|c|c|c|c|c|c|c|}
\hline Variable & No. of items & GFI & CFI & NFI & RMSEA & USRW & SE & SRW \\
\hline $\begin{array}{l}5.4 \text { Environmental emergency } \\
\text { plans }\end{array}$ & & & & & & 0.93 & 0.11 & $0.62^{\star \star \star}$ \\
\hline $\begin{array}{l}5.5 \text { Policies for substitution of } \\
\text { polluting and materials and } \\
\text { conservation of virgin } \\
\text { materials }\end{array}$ & & & & & & 0.73 & 0.09 & $0.56^{\star \star \star}$ \\
\hline $\begin{array}{l}\text { 5.6 Designs facilitating } \\
\text { reduction of resource con- } \\
\text { sumption and waste genera- } \\
\text { tion during production, } \\
\text { distribution and product usage }\end{array}$ & & & & & & 0.61 & 0.14 & $0.62^{\star \star \star}$ \\
\hline $\begin{array}{l}5.7 \text { Preference for green } \\
\text { products in purchasing }\end{array}$ & & & & & & 1.05 & 0.13 & $0.66^{\star \star \star}$ \\
\hline $\begin{array}{l}5.8 \text { Natural environment } \\
\text { training for employees }\end{array}$ & & & & & & 0.87 & 0.13 & $0.61 \star \star \star$ \\
\hline $\begin{array}{l}5.9 \text { Selection of cleaner } \\
\text { transportation methods }\end{array}$ & & & & & & 0.81 & 0.13 & $0.53 \star \star \star$ \\
\hline $\begin{array}{l}5.10 \text { Responsible disposal of } \\
\text { waste and residues, and recu- } \\
\text { peration and recycling systems }\end{array}$ & & & & & & 0.58 & 0.10 & $0.51^{\star \star \star}$ \\
\hline $\begin{array}{l}5.11 \text { Emission filters and end- } \\
\text { of-pipe controls }\end{array}$ & & & & & & 0.64 & 0.11 & $0.51^{\star \star \star}$ \\
\hline $\begin{array}{l}5.12 \text { Process design for } \\
\text { reducing energy and natural } \\
\text { resources consumption in } \\
\text { operations }\end{array}$ & & & & & & 0.76 & 0.10 & $0.65^{\star \star \star}$ \\
\hline $\begin{array}{l}\text { 5.13 Production planning } \\
\text { reducing energy and natural } \\
\text { resources consumption in } \\
\text { operations }\end{array}$ & & & & & & 0.70 & & $0.60 \star \star \star$ \\
\hline $\begin{array}{l}5.14 \text { Regular voluntary } \\
\text { information about environ- } \\
\text { mental management to } \\
\text { stakeholders }\end{array}$ & & & & & & 0.92 & 0.10 & $0.61 \star \star \star$ \\
\hline $\begin{array}{l}5.15 \text { Policies for preventing } \\
\text { direct and indirect pollution } \\
\text { of soil, water, and air }\end{array}$ & & & & & & 0.73 & 0.13 & $0.64 \star \star \star$ \\
\hline $\begin{array}{l}5.16 \text { Systems and techniques } \\
\text { for producing environmen- } \\
\text { tally safe products }\end{array}$ & & & & & & 0.81 & 0.10 & $0.58^{\star \star \star}$ \\
\hline $\begin{array}{l}5.17 \text { Mechanism for support- } \\
\text { ing research and development } \\
\text { of environmental technologies }\end{array}$ & & & & & & 1.11 & 0.12 & $0.66^{\star \star \star}$ \\
\hline
\end{tabular}


TABLE V

continued

\begin{tabular}{|c|c|c|c|c|c|c|c|c|}
\hline Variable & No. of items & GFI & CFI & NFI & RMSEA & USRW & SE & SRW \\
\hline 6. CSR supplier & 5 & 0.97 & 0.97 & 0.94 & 0.09 & & & \\
\hline $\begin{array}{l}6.1 \text { Inspection of supplier } \\
\text { facilities for health, safety and } \\
\text { environmental aspects }\end{array}$ & & & & & & 1.00 & & $0.72 \star \star \star$ \\
\hline $\begin{array}{l}6.2 \text { Policy to ensure ethical } \\
\text { and friendly procurement at } \\
\text { suppliers place }\end{array}$ & & & & & & 1.13 & 0.22 & $0.80 \star \star \star$ \\
\hline $\begin{array}{l}6.3 \text { Policy to pay and receive } \\
\text { competitive market prices } \\
\text { timely to/from the supplier }\end{array}$ & & & & & & 0.20 & 0.09 & $0.26 \star \star$ \\
\hline $\begin{array}{l}6.4 \text { Policy on restrictions on } \\
\text { the use of child labor, sweat } \\
\text { shop and violation of human } \\
\text { rights at the supplier's place }\end{array}$ & & & & & & 0.97 & 0.22 & $0.63 \star \star \star$ \\
\hline $\begin{array}{l}6.5 \text { Policy for social account- } \\
\text { ability or sustainable reporting } \\
\text { by the supplier }\end{array}$ & & & & & & 0.75 & 0.21 & $0.62 \star \star \star \star$ \\
\hline
\end{tabular}

USR $W$ unstandardized regression weight, SE standard error, SR $W$ standardized regression weight.

${ }^{\dagger} p<0.10 ;{ }^{\star} p<0.05 ;{ }^{\star \star} p<0.01 ;{ }^{\star \star \star} p<0.001$.

\section{References}

Aaker, D.: 1994, 'Building a Brand: The Saturn Story', California Management Review 36(2), 114-121.

Agle, B. R., R. K. Mitchell and J. A. Sonnenfield: 1999, 'Who Matters to CEOs? An Investigation of Stakeholder Attributes and Salience, Corporate Performance, and CEO Values', Academy of Management Journal 42(5), 507-525.

Ahmed, N. Z., R. V. Montagno and R. J. Firenze: 1998, 'Organizational Performance and Environmental Consciousness: An Empirical Study', Management Decision 36(2), 57-62.

Allen, F. E.: 11 August 1992, 'Reducing Toxic Waste Produces Quick Results', The Wall Street Journal B1.

Alshimmiri, T.: 2004, 'Board Composition, Executive Remuneration and Corporate Performance: The Case of REITS', Corporate Ownership and Control 2(1), 104119.

Alvarez, G. M. J., J. J. Burgos and L. J. J. Cespedes: 2001, 'An Analysis of Environmental Management, Organizational Context and Performance of Spanish Hotels', Omega 29(6), 457-471.

Anderson, J. C. and A. W. Frankle: 1980, 'Voluntary Social Reporting: An Iso-Beta Portfolio Analysis', The Accounting Review 55(3), 467-479.
Arora, B. and R. Puranik: 2004, 'A Review of Corporate Social Responsibility in India', Development 47(3), 93100.

Ashforth, B. E. and F. Mael: 1989, 'Social Identity Theory and the Organization', Academy of Management Review 14(1), 20-39.

Aupperle, K. E., A. B. Carroll and J. D. Hatfield: 1985, 'An Empirical Examination of the Relationship Between Corporate Social Responsibility and Profitability', Academy of Management Review 28(2), 446-463.

Barney, J. B. and M. H. Hansen: 1994, 'Trustworthiness as a Source of Competitive Advantage', Strategic Management Journal (Winter Special Issue) 15, 175-190.

Barrett, S.: 1992, 'Strategy and the Environment', Columbia Journal of World Business 27(3/4), 202-209.

Belal, A.: 2001, 'A Study of Corporate Social Disclosures in Bangladesh', Managerial Auditing Journal 15(5), 274289.

Belk, R. W.: 1988, 'Possessions and the Extended Self, Journal of Consumer Research 15(2), 139-168.

Benito, J. G. and G. Benito: 2005, 'Environmental Proactivity and Business Performance: An Empirical Analysis', Omega 33(1), 1-15.

Berman, S. L., A. C. Wicks, S. Kotha and T. M. Jones: 1999, 'Does Stakeholder Orientation Matter? The Relationship Between Stakeholder Management 
Models and Firm Financial Performance', Academy of Management Journal 42(5), 488-506.

Black, B. S. and V. S. Khanna: 2007, 'Can Corporate Governance Reforms Increase Firms' Market Values? Evidence from India', Journal of Empirical Legal Studies 4(4), 749-796.

Boardman, A. E. and A. R. Vining: 1989, 'Ownership and Performance in Competitive Environments', Journal of Law and Economics 32(1), 1-33.

Boli, J. and D. Hartsuiker: 2001, 'World Culture and Transnational Corporations: Sketch of a Project', Paper Presented at the International Conference on Effects of and Responses to Globalization, Istanbul.

Bollen, K. A.: 1989, Structural Equations with Latent Variables (John Wiley \& Sons, New York).

Bollen, K. and R. Lenox: 1991, 'Conventional Wisdom on Measurement: A Structural Equation Perspective', Psychological Bulletin 110(2), 305-314.

Bouchard, T. J. Jr.: 1976, 'Unobtrusive Measures: An Inventory of Uses', Sociological Methods and Research 4(3), 267-300.

Boulding, W. and M. A. Kirmani: 1993, 'A Consumer Side Experimental Examination of Signaling Theory: Do Consumers Perceive Warranties as Signals of Quality?', Journal of Consumer Research 20(1), 111-128.

British Council, UNDP, CII and Pricewaterhouse Coopers: 2002, 'Corporate Social Responsibility Survey', A Survey by British Council, UNDP, CII and Pricewaterhouse Coopers, India.

Bromiley, P. and A. Marcus: 1989, 'The Deterrent to Dubious Corporate Behavior: Profitability, Probability, and Safety Recalls', Strategic Management Journal 10(3), 233-250.

Brown, T. J. and P. A. Dacin: 1997, 'The Company and the Product: Corporate Associations and Consumer Product Responses', Journal of Marketing 61(1), 68-85.

Brugmann, J. and C. K. Prahalad: 2007, 'Co-Creating Business's New Social Compact', Harvard Business Review 85(2), 80-90.

Burke, L. and J. M. Logsdon: 1996, 'How Corporate Social Responsibility Pays Off, Long Range Planning 29(4), 495-502.

Business Week: Oct 2002, 'Best and Worst Boards Survey: How Corporate Scandals are Sparking a Revolution in Governance', http://www.businessweek.com/magazine/ content/02_40/b3802001.htm. Accessed 16 May 2006.

Chapple, W. and J. Moon: 2005, 'Corporate Social Responsibility in Asia: A Seven-Country Study of CSR Web Site Reporting', Business E Society 44(4), 415-441.

Chen, K. H. and R. W. Metcalf: 1980, 'The Relationship Between Pollution Control Records and Financial
Indicators Revisited', The Accounting Review 55(1), 168-177.

Christman, P.: 2000, "Effects of "Best Practices" of Environmental Management on Cost Advantage: The Role of Complementary Assets', Academy of Management Journal 43(4), 663-680.

Clair, J. A., J. Milliman and I. I. Mitroff: 1995, 'Clash or Cooperation? Understanding Environmental Organizations and Their Relationships to Business', in J. E. Post (ed.) and D. Collins and M. Starik (Vol. eds.), Research in Corporate Social Performance and Policy: Sustaining the Natural Environment - Empirical Studies on the Interface Between Nature and Organizations (JAI Press, Greenwich, CT), Supplement 1, pp. 163-193.

Clarkson, M. B. E.: 1995, 'A Shareholder Framework for Analyzing and Evaluating Corporate Social Performance', Academy of Management Review 20(1), 571-610.

CLSA (Credit Lyonnais Securities Asia): October 2000, 'Report on Corporate Governance: Emerging Markets Equities Research', http://web.management.mcgill. ca/Art.Durnev/clsa_2000.pdf. Accessed 5 January 2009.

Cochran, P. and R. Wood: 1984, 'Corporate Social Responsibility and the Financial Performance', Academy of Management Journal 27(1), 42-56.

Coles, J. W., V. B. McWilliams and N. Sen: 2001, 'An Examination of the Relationship of Governance Mechanisms to Performance', Journal of Management 27(1), 23-50.

Coombes, P. and M. Watson: 2000, 'Three Surveys on Corporate Governance', McKinsey Quarterly 4, 74-77.

Copeland, T., T. Koller and J. Murrin: 2000, Valuation: Measuring and Managing the Value of Companies (John Wiley \& Sons, Inc, New York).

CREM (Consultancy, Research for Environmental Management): 2004, Corporate Social Responsibility in India, Policy and Practices of Dutch Companies (CREM, Amsterdam).

CSM (Centre for Social Markets): 2001, 'Corporate Social Responsibility: Perceptions of Indian Business', A Report by CSM, Calcutta, India, www.csmworld. org/public/pdf/social_respons.pdf. Accessed 18 January 2005.

Dahya, J. and J. J. McConnell: 2007, 'Board Composition, Corporate Performance, and the Cadbury Committee Recommendation', Journal of Financial and Quantitative Analysis 42(3), 535-564.

Dalton, D. R., C. M. Daily, A. E. Ellstrand and J. L. Johnson: 1998, 'Number of Directors and Financial Performance: A Meta-Analysis', Academy of Management Journal 42(6), 674-686.

Davidson, W. N., P. R. Chandy and M. Cross: 1987, 'Large Losses, Risk Management and Stock Returns in 
the Airline Industry', Journal of Risk and Insurance 55(1), 162-172.

Davidson, W. N. and D. L. Worell: 1988, 'The Impact of Announcements of Corporate Illegalities on Shareholder Returns', Academy of Management Journal 31(1), 195-200.

Dunn, D. and K. Yamashita: 2003, 'A Changed World, Microcapitalism and the Mega-Corporation', Harvard Business Review 81(8), 46-54.

Dutton, J. E., J. M. Dukerich and C. V. Harquail: 1994, 'Organizational Images and Member Identification', Administrative Science Quarterly 39(2), 239-263.

Environics International: 2001, eFlash Report: CSR Index (Environics International, Toronto).

Epstein, M. J. and M. J. Roy: 2001, 'Sustainability in Action: Identifying and Measuring the Key Performance Drivers', Long Range Planning 34(5), 585-604.

Financial Express: December 19 2006, 'New Norms to Gauge Toxins in Colas Soon', p. 1.

Fomburn, C. and M. Shanley: 1990, 'What's in a Name? Reputation Building and Corporate Strategy', Academy of Management Journal 33(2), 233-258.

Fowler, K. L. and D. R. Schmidt: 1988, 'Tender Offers, Acquisitions, and Subsequent Performance in Manufacturing Firms', Academy of Management Journal 31(4), 962-974.

Freedman, N. and B. Jaggi: 1982, 'Pollution Disclosures, Pollution Performance, and Economic Performance', Omega 10(2), 167-176.

Freeman, R. E.: 1984, Strategic Management: A Stakeholder Approach (Pitman Publishing, Boston, MA).

Frooman, J.: 1997, 'Socially Irresponsible and Illegal Behavior and Shareholder Wealth: A MetaAnalysis of Event Studies', Business \& Society 36(3), 221-249.

Galbreath, J.: 2006, 'Does Primary Stakeholder Management Positively Affect the Bottom Line? Some Evidence from Australia', Management Decision 44(8), 1106-1121.

Ganesh, G.: February 15 2001, 'PSUs vs. Private Companies: The Reality Check', Business Line, Internet edition, http://www.hinduonnet.com/businessline/2001/02/ 15/stories/041546mn.htm. Accessed 23 December 2008.

Gildea, R. L.: 1994, 'Consumer Survey Confirms Corporate Social Action Affects Buying Decisions', Public Relations Quarterly 39(4), 20-22.

Gillentine, A.: February 17 2006, 'Timberland to Provide "Nutritional Label" for All Shoes', The Colorado Springs Business Journal, http://www.allbusiness.com/ north-america/united-states-colorado/1034748-1. html. Accessed 15 November 2007.
GMI Poll: 2005, More than a Third of all Consumers Boycott at Least One Brand (GMI, USA), http://www.gmimr.com.

Goodpaster, K.: 1998, 'Business Ethics', in G. L. Cooper and C. Argyris (eds.), The Concise Blackwell Encyclopedia of Management (Blackwell, Oxford), pp. 56-60.

Govindarajan, V.: 1984, 'Appropriateness of Accounting Data in Performance Evaluation: An Examination of Environmental Uncertainty as an Intervening Variable', Accounting, Organizations and Society 9(2), 125135.

Govindarajan, V. and A. K. Gupta: 1985, 'Linking Control Systems to Business Unit Strategy: Impact on Performance', Accounting, Organizations, and Society 10(1), 51-66.

Graafland, J. and B. W. van de Ven: 2006, 'Strategic and Moral Motivation for Corporate Social Responsibility', Journal of Corporate Citizenship 22(Summer), 111-123.

Graves, S. and S. Waddock: 1994, 'Institutional Owners and Corporate Social Performance', Academy of Management Journal 37(4), 1034-1046.

Greening, D. W. and D. B. Turban: 2000, 'Corporate Social Performance as a Competitive Advantage in Attracting a Quality Workforce', Business \& Society 39(3), 254-280.

Greeno, J. L. and S. N. Robinson: 1992, 'Rethinking Corporate Environmental Management', Columbia Journal of World Business 27(3-4), 222-232.

GRI (Global Reporting Initiatives): 2002, Sustainability Reporting Guidelines, Global Reporting Initiatives (GRI, Amsterdam), http://www.globalreporting.org.

Griffin, J. J. and J. F. Mahon: 1997, 'The Corporate Social Performance and Corporate Financial Performance Debate', Business \& Society 36(1), 5-31.

Gupta, A.: 2005, A Report on Effectiveness of the Breaseeding Promotion Network of India (BPNI) Activities on Infant Feeding Policies and Practices in India, http://www. bpni.org/cgi/effect.asp. Accessed 16 April 2005.

Handelman, J. M. and S. J. Arnold: 1999, 'The Role of Marketing Actions with a Social Dimension: Appeals to the Institutional Environment', Journal of Marketing 63(3), 33-48.

Handique, M.: 2008, 'Companies Focus More on Social Responsibility Projects in Villages', livemint.com: The Wall Street Journal, http://www.livemint.com/2008/ 03/11000146/Companies-focus-more-on-social.html. Accessed on 04 February 2009.

Hayes, A. S. and J. Pereira: September 20 1990, 'Facing a Boycott, Many Companies Bend', Wall Street Journal, pp. 1, 24.

Heal, G.: 2005, 'Corporate Social Responsibility: An Economic and Financial Framework', The Geneva 
Papers on Risk and Insurance - Issues and Practice 30(3), 387-409.

Herbert, B.: 1996, 'Nike's Pyramid Scheme', New York Times, June 10, A.17-A.23.

Hoeffler, S. and K. L. Keller: 2002, 'Building Brand Equity Through Corporate Societal Marketing', Journal of Public Policy and Marketing 21(1), 78-89.

Hoque, Z.: 2004, 'A Contingency Model of the Association Between Strategy, Environmental Uncertainty and Performance Measurement: Impact on Firm Performance', International Business Review 13(4), 485502.

Huselid, M.: 1995, 'The Impact of Human Resource Management Practices on Turnover, Productivity and Corporate Financial Performance', Academy of Management Journal 38(3), 635-672.

Husted, B. W.: 2003, 'Governance Choices for Corporate Social Responsibility: To Contribute, Collaborate or Internalize?', Long Range Planning 36(5), 481-498.

IndiaPRwire.com: 2007, 'Announcing Karmayog CSR Ratings of India's Top 500 Companies', http://www. indiaprwire.com/pressrelease/other/200712156225. htm. Accessed 10 December 2008.

Informatics (India) Limited: 2003, India Business Insight Database (Informatics (India) Limited, India), http:// ibid.informindia.co.in/bsearch.asp.

Ittner, C. D. and D. F. Larcker: 1998, 'Innovations in Performance Measurement: Trends and Research Implications', Journal of Management Accounting Research 10(1), 205-238.

Ittner, C. D. and D. F. Larcker: 2000, 'Non-Financial Performance Measures: What Works and What Does Not',Knowledge@Wharton at http://knowledgewharton. upenn.edu/article.cfm?articleid=279. Accessed 10 December 2008.

Kaplan, R. S. and D. P. Norton: 2001, 'Transforming the Balanced Scorecard from Performance Measurement to Strategic Management: Part 1', Accounting Horizon 15(1), 87-104.

Khan, A. F. and A. Atkinson: 1987, 'Managerial Attitudes to Social Responsibility: A Comparative Study in India and Britain', Journal of Business Ethics 6(6), 419-432.

Kinder, P., S. Lydenberg and B. Cohen: 2005, 'Socrates: The Corporate Social Ratings Monitor', http://www. kld.com/research/socrates/indicators.html. Accessed 12 April 2005.

Kirmani, A.: 1997, 'Advertising Repetition as a Signal of Quality: If It's Advertised So Much, Something Must Be Wrong', Journal of Advertising 26(3), 77-90.

Klassen, R. D. and C. P. Mc Laughlin: 1996, 'The Impact of Environmental Management on Firm Performance', Management Science 42(8), 1199-1214.
Koys, D. J.: 2001, 'The Effects of Employee Satisfaction, Organizational Citizenship Behavior, and Turnover on Organizational Effectiveness: A Unit-Level, Longitudinal Study', Personnel Psychology 54(1), 101-114.

KPMG: 2005, KPMG International Survey of Corporate Responsibility Reporting 2005 (KPMG Global Sustainability Services: Amsterdam), http://www.kpmg.org.

Krishna, C. G.: 1992, Corporate Social Responsibility in India (Mittal Publications, New Delhi).

Kumar, R., D. F. Murphy and V. Balsari: 2001, Altered Images: The 2001 State of Corporate Responsibility in India Poll. Understanding and Encouraging Corporate Responsibility in South Asia - Update 1 (Tata Energy Research Institute, New Delhi).

Landon, S. and C. E. Smith: 1997, 'The Use of Quality and Reputation Indicators by Consumers: The Case of Bordeaux Wine', Journal of Consumer Policy 20(3), 285-297.

Lee, M. P.: 2008, 'A Review of the Theories of Corporate Social Responsibility: Its Evolutionary Path and the Road Ahead', International Journal of Management Reviews 10(1), 53-73.

Leff, E.: 2004, Community Development Vehicles Adopted by Corporates: An Exploration (Asia Pacific Philanthropy Consortium, Centre for Advancement of Philanthropy and Partner-in-Change, New Delhi).

Lev, B.: 2000, 'Knowledge Management: Fad or Need?', Research Technology Management 43(5), 9-10.

Luo, X. and C. B. Bhattacharya: 2006, 'Corporate Social Responsibility, Customer Satisfaction and Market Value', Journal of Marketing 70(4), 1-18.

Mahajan, A.: 2004, 'Enhancing Business Community Relations: The Role of Volunteers in Promoting Global Corporate Citizenship', National Research Report, New Delhi.

Maignan, I. and O. C. Ferrell: 2001, 'Corporate Citizenship as a Marketing Instrument - Concepts, Evidence and Research Directions', European Journal of Marketing 35(3/4), 457-484.

Margolis, J. D. and J. P. Walsh: 2003, 'Misery Loves Companies: Rethinking Social Initiatives by Business', Administrative Science Quarterly 48(2), 268-305.

McGuire, J. B., A. Sundgren and T. Schneeweis: 1988, 'Corporate Social Responsibility and Firm Financial Performance', Academy of Management Journal 31(4), 854-872.

McVea, J. F. and R. E. Freeman: 2005, 'A Names-andFaces Approach to Stakeholder Management', Journal of Management Enquiry 14(1), 57-69.

Miles, M. P. and J. G. Covin: 2000, 'Environmental Marketing: A Source of Reputational, Competitive, and Financial Advantage', Journal of Business Ethics 23(3), 299-311. 
Moore, G.: 2001, 'Corporate Social and Financial Performance: An Investigation in the U.K. Supermarket Industry', Journal of Business Ethics 34(3/4), 299-315.

Moskowitz, M.: 1972, 'Choosing Socially Responsible Stocks', Business and Society 1(Spring), 71-75.

Nemkumar, H.: 2000, 'India: A Research Head's Perspective', Report on Corporate Governance: Emerging Markets Equities Research, http://web.management. mcgill.ca/Art.Durnev/clsa_2000.pdf. Accessed 5 January 2009 , pp. 60-61.

Ong, L. K.: 2003, Does Adding Non-Financial Value Drivers to a Summary Financial Measure Improve the Learning and Performance of Managers? (University of South California, Los Angeles).

Orlitzky, M., F. L. Schmidt and S. L. Rynes: 2003, 'Corporate Social and Financial Performance: A MetaAnalysis', Organization Studies 24(3), 403-411.

Owen, C. L. and R. F. Scherer: 1993, 'Social Responsibility and Market Share', Review of Business 15(1), 11-17.

Pava, M. L. and J. Krausz: 1996, 'The Association Between Corporate Social Responsibility and Financial Performance - The Paradox of Social Cost', Journal of Business Ethics 15(3), 321-357.

PiC (Partners in Change): 2004, Third Report on Corporate Involvement in Social Development in India (PiC, New Delhi).

Podsakoff, P. M., S. B. MacKenzie and N. P. Podsakoff: 2003, 'Common Method Biases in Behavioural Research: A Critical Review of the Literature and Recommended Remedies', Journal of Applied Psychology 88(5), 879-903.

Prahalad, C. K. and G. Hamel: 1990, 'The Core Competence of the Corporation', Harvard Business Review 68(3), 79-91.

Prowess: 2005, Prowess Version 2.5 (CMIE, New Delhi), www.cmie.com.

Riordan, C. M., R. D. Gatewood and J. B. Bill: 1997, 'Corporate Image: Employee Reactions and Implications for Managing Corporate Social Performance', Journal of Business Ethics 16(4), 401-412.

Robins, J. and M. Wiersema: 1995, 'A Resource-Based Approach to the Multi-Business Firm: Empirical Analysis of Portfolio Interrelationships and Corporate Financial', Strategic Management Journal 16(4), 277-299.

Rockefeller, R. C.: 2003, 'Turn Public Problems into Private Account', Harvard Business Review 81(8), 129137.

Rosewicz, B.: April 20 1990, 'Americans are Willing to Sacrifice to Reduce Pollution, They Say', The Wall Street Journal (New York), p. Al.

Ruf, B. M., K. Muralidhar, R. M. Brown, J. J. Janney and K. Paul: 2001, 'An Empirical Investigation of the
Relationship Between Change in Corporate Social Performance and Financial Performance: A Stakeholder Theory Perspective', Journal of Business Ethics 32(2), 143-156.

Russo, M. V. and P. A. Fouts: 1997, 'A Resource Based Perspective on Corporate Environmental Performance and Profitability', Academy of Management Journal 40(3), 534-559.

Sagar, P. and A. Singla: 2004, 'Trust and Corporate Social Responsibility: Lessons from India', Journal of Communication Management 8(3), 282-290.

SAI (Social Accountability International): 2001, Social Accountability 8000 (SAI, New York).

Schmidheiny, S.: 1992, Changing Course: A Global Business Perspective on Development and the Environment (MIT Press, Cambridge, MA).

Schwaiger, M.: 2004, 'Components and Parameters of Corporate Reputation - An Empirical Study', Schmalenbach Business Review 56(1), 46-71.

Sen, S. and C. B. Bhattacharya: 2001, 'Does Doing Good Always Lead to Doing Better? Consumer Reactions to Corporate Social Responsibility', Journal of Marketing Research 38(2), 225-243.

Sen, S., C. B. Bhattacharya and D. Korschun: 2006, 'The Role of Corporate Social Responsibility in Strengthening Multiple Stakeholder Relationships: A Field Experiment', Journal of the Academy of Marketing Science 34(2), 158-166.

Shane, P. and B. Spicer: 1983, 'Market Response to Environmental Information Produced Outside the Firm', Accounting Review 58(July), 521-538.

Singh, R. and K. Bhagat: 2004, 'Corporate Initiatives in Indian Agriculture', Indian Management 43(2), 72-79.

Somavia, J.: 2000, 'Business. Its Direct Stake in Putting Human Needs First', UN Chronicle 37(2), 42.

Sood, A. and B. Arora: 2006, 'The Political Economy of Corporate Responsibility in India', Technology, Business and Society (18), United Nations Research Institute for Social Development (UNRISD) Program Paper, Geneva.

Springer, J.: 2006, 'Whole Foods Posts 22\% Sales Growth', Supermarket News 54(7), 8.

Teoh, H. Y. and G. Y. Shiu: 1990, 'Attitudes Towards Corporate Social Responsibility and Perceived Importance of Social Responsibility Information Characteristics in a Decision Context', Journal of Business Ethics 9(1), 71-77.

Teoh, S. H., I. Welch and C. P. Wazzan: 1999, 'The Effect of Socially Activist Investment Policies on the Financial Markets: Evidence from the South African Boycott', Journal of Business 72(1), 35-89.

Tsang, E. W. K. and K. Kwan: 1999, 'Replication and Theory Development in Organizational Science: A 
Critical Realist Perspective', Academy of Management Review 24(4), 759-780.

Turban, D. B. and D. W. Greening: 1997, 'Corporate Social Performance and Organizational Attractiveness to Prospective Employees', Academy of Management Journal 40(3), 658-763.

Ullman, A. A.: 1985, 'Data in Search of a Theory: A Critical Examination of the Relationships Among Social Performance, Social Disclosure, and Economic Performance of U.S. Firms', Academy of Management Review 10(3), 540-557.

Venkatraman, N. and V. Ramanujam: 1987, 'Measurement of Business Economic Performance: An Examination of Method Convergence', Journal of Management 13(1), 109-122.

Verschoor, C. C.: 1998, 'A Study of the Link Between a Corporation's Financial Performance and Its Commitment to Ethics', Journal of Business Ethics 17(13), 1509-1516.

Vogel, D.: 2005, The Market for Virtue: The Potential and Limits of Corporate Social Responsibility (Brookings Institution Press, Washington, DC).

Waddock, S. A. and S. B. Graves: 1997, 'The Corporate Social Performance - Financial Performance Link', Strategic Management Journal 18(4), 303-320.
Wood, D. J.: 1991, 'Corporate Social Performance Revisited', Academy of Management Review 16(4), 691718.

Wright, P. and S. Ferris: 1997, 'Agency Conflict and Corporate Strategy: The Effect of Divestment on Corporate Value', Strategic Management Journal 18(1), 77-83.

Wu, M. L.: 2006, 'Corporate Social Performance, Corporate Financial Performance, and Firm Size: A MetaAnalysis', Journal of American Academy of Business 8(1), 163-171.

Youndt, M., S. Snell, J. Dean and D. Lepak: 1996, 'Human Resource Management Manufacturing Strategy and Firm Performance', Academy of Management Journal 39(4), 836-866.

Zahra, S. A. and M. S. Latour: 1987, 'Corporate Social Responsibility and Organizational Effectiveness: A Multivariate Approach', Journal of Business Ethics 6(6), 459-467.

Indian Institute of Technology Kharagpur, Kharagpur, India E-mail:mishrasupriti@gmail.com 